\title{
Semivolatile POA and parameterized total combustion SOA in CMAQv5.2: impacts on source strength and partitioning
}

\author{
Benjamin N. Murphy ${ }^{1}$, Matthew C. Woody ${ }^{1}$, Jose L. Jimenez ${ }^{2,3}$, Ann Marie G. Carlton ${ }^{4}$, Patrick L. Hayes ${ }^{5}$, \\ Shang Liu ${ }^{6}$, Nga L. Ng ${ }^{7,8}$, Lynn M. Russell ${ }^{9}$, Ari Setyan ${ }^{10}$, Lu Xu ${ }^{7}$, Jeff Young ${ }^{1}$, Rahul A. Zaveri ${ }^{11}$, Qi Zhang ${ }^{12}$, and \\ Havala O. T. Pye ${ }^{1}$ \\ ${ }^{1}$ National Exposure Research Laboratory, US Environmental Protection Agency, Research Triangle Park, NC, USA \\ ${ }^{2}$ Cooperative Institute for Research in Environmental Sciences, University of Colorado Boulder, Boulder, CO, USA \\ ${ }^{3}$ Department of Chemistry and Biochemistry, University of Colorado Boulder, Boulder, CO, USA \\ ${ }^{4}$ Department of Chemistry, University of California, Irvine, Irvine, CA 92697, USA \\ ${ }^{5}$ Department of Chemistry, Université de Montréal, Montréal, QC, Canada \\ ${ }^{6}$ School of Earth and Space Sciences, University of Science and Technology of China, Hefei, Anhui, China \\ ${ }^{7}$ School of Chemical and Biomolecular Engineering, Georgia Institute of Technology, Atlanta, GA, USA \\ ${ }^{8}$ School of Earth and Atmospheric Sciences, Georgia Institute of Technology, Atlanta, GA, USA \\ ${ }^{9}$ Scripps Institution of Oceanography, University of California, San Diego, La Jolla, CA, USA \\ ${ }^{10}$ EMPA, Swiss Federal Laboratories for Materials Science and Technology, 8600 Dübendorf, Switzerland \\ ${ }^{11}$ Atmospheric Sciences and Global Change Division, Pacific Northwest National Laboratory, Richland, WA, USA \\ ${ }^{12}$ Department of Environmental Toxicology, University of California, Davis, Davis, CA, USA
}

Correspondence to: Benjamin N. Murphy (murphy.benjamin@epa.gov)

Received: 2 March 2017 - Discussion started: 15 March 2017

Revised: 21 July 2017 - Accepted: 24 July 2017 - Published: 20 September 2017

\begin{abstract}
Mounting evidence from field and laboratory observations coupled with atmospheric model analyses shows that primary combustion emissions of organic compounds dynamically partition between the vapor and particulate phases, especially as near-source emissions dilute and cool to ambient conditions. The most recent version of the Community Multiscale Air Quality model version 5.2 (CMAQv5.2) accounts for the semivolatile partitioning and gas-phase aging of these primary organic aerosol (POA) compounds consistent with experimentally derived parameterizations. We also include a new surrogate species, potential secondary organic aerosol from combustion emissions (pcSOA), which provides a representation of the secondary organic aerosol (SOA) from anthropogenic combustion sources that could be missing from current chemical transport model predictions. The reasons for this missing mass likely include the following: (1) unspeciated semivolatile and intermediate volatility organic compound (SVOC and IVOC, respectively) emissions missing from current inventories, (2) multigenerational aging of organic vapor products from known SOA precur-
\end{abstract}

sors (e.g., toluene, alkanes), (3) underestimation of SOA yields due to vapor wall losses in smog chamber experiments, and (4) reversible organic compounds-water interactions and/or aqueous-phase processing of known organic vapor emissions. CMAQ predicts the spatially averaged contribution of pcSOA to OA surface concentrations in the continental United States to be 38.6 and $23.6 \%$ in the 2011 winter and summer, respectively.

Whereas many past modeling studies focused on a particular measurement campaign, season, location, or model configuration, we endeavor to evaluate the model and important uncertain parameters with a comprehensive set of United States-based model runs using multiple horizontal scales (4 and $12 \mathrm{~km}$ ), gas-phase chemical mechanisms, and seasons and years. The model with representation of semivolatile POA improves predictions of hourly OA observations over the traditional nonvolatile model at sites during field campaigns in southern California (CalNex, MayJune 2010), northern California (CARES, June 2010), the southeast US (SOAS, June 2013; SEARCH, January and 
July, 2011). Model improvements manifest better correlations (e.g., the correlation coefficient at Pasadena at night increases from 0.38 to 0.62 ) and reductions in underprediction during the photochemically active afternoon period (e.g., bias at Pasadena from -5.62 to $-2.42 \mu \mathrm{g} \mathrm{m}^{-3}$ ). Daily averaged predictions of observations at routine-monitoring networks from simulations over the continental US (CONUS) in 2011 show modest improvement during winter, with mean biases reducing from 1.14 to $0.73 \mu \mathrm{g} \mathrm{m}^{-3}$, but less change in the summer when the decreases from POA evaporation were similar to the magnitude of added SOA mass. Because the model-performance improvement realized by including the relatively simple pcSOA approach is similar to that of more-complicated parameterizations of OA formation and aging, we recommend caution when applying these morecomplicated approaches as they currently rely on numerous uncertain parameters.

The pcSOA parameters optimized for performance at the southern and northern California sites lead to higher OA formation than is observed in the CONUS evaluation. This may be due to any of the following: variations in real pcSOA in different regions or time periods, too-high concentrations of other OA sources in the model that are important over the larger domain, or other model issues such as loss processes. This discrepancy is likely regionally and temporally dependent and driven by interferences from factors like varying emissions and chemical regimes.

\section{Introduction}

A substantial fraction of atmospheric particles are made of organic compounds (Zhang et al., 2007; Murphy et al., 2006). This is true over the continental United States, where pollutants introduced by human sources often interact in complex ways with compounds from natural sources (Hallquist et al., 2009; De Gouw and Jimenez, 2009). In order to fully describe the impacts that human activities have on public health, regional haze, and climate change via airborne particles, we must be able to quantify the capacity for relevant organic compounds to form and maintain airborne particulate mass (Carlton et al., 2010). To achieve this end, atmospheric models routinely rely on estimates of volatility (i.e., vapor pressure or saturation concentration) and solubility in a predominantly aqueous phase. Although research efforts demonstrate clearly the importance of organic solubility in water on phase partitioning and particle viscosity (Zhang et al., 2012; Hodas et al., 2015; Pajunoja et al., 2015; Riipinen et al., 2015; Wania et al., 2015; Isaacman-VanWertz et al., 2016; Jathar et al., 2016b; Pye et al., 2017; Shiraiwa et al., 2017), improvements to the conceptual model of organic compounds partitioning into an organic-rich particulate phase alone are useful before the entire system is treated holistically.
It is clear from available experimental data that primary organic aerosol (POA), which is operationally defined as the population of organic compounds that are emitted in the particulate phase, is a more dynamic quantity than originally prescribed in chemical transport models (Lipsky and Robinson, 2006; Donahue et al., 2009; Grieshop et al., 2009; Huffman et al., 2009b, a; May et al., 2013a, b, c). Not only do these studies show that POA evaporates upon dilution of exhaust from multiple sources and that it is often more volatile than secondary organic aerosol (SOA; which had been treated as semivolatile in models), but the semivolatile vapors that are produced are most likely susceptible to continued oxidation in the gas phase. Robinson et al. (2007) first demonstrated, by applying a chemical transport model to predict air quality over the eastern US (EUS) in July 2001, that treating primary particulate compounds as semivolatile improves model performance for bulk organic aerosol (OA) mass predictions and better predicts the relative importance of POA and SOA, which is formed from the oxidation products of volatile organic compound (VOC) gases. Moreover, Robinson et al. (2007) predicted that organic compounds with intermediate volatility (IVOCs), that is, volatility higher than that of semivolatile organic compounds (SVOCs) and lower than traditionally defined VOCs, were emitted in significant quantities and that their oxidation products could condense and form OA downwind of combustion sources. An IVOC mass emission scale factor of 1.5 times the POA + SVOC emission rate led to significant contribution of OA derived from IVOCs when applied in their model. However, that scale factor was uncertain, as was the overall efficiency with which those IVOCs formed SOA (Shrivastava et al., 2008).

More recently, both experimental and model studies have sought to constrain combustion-related SVOC and IVOC emissions as well as their subsequent SOA yields (Tkacik et al., 2012; Jathar et al., 2014; Zhao et al., 2014, 2016b; Ots et al., 2016; Jathar et al., 2017). Progress has been made characterizing the overall significance of this OA production pathway, but the variability among vehicles and other combustion sources is uncertain, as are the effects of operating (e.g., load, burn temperature) and environmental conditions. Additional limitations exist in our understanding of other important processes for SOA formation. First, multigenerational aging of anthropogenic and biogenic condensable organic vapors could affect OA partitioning if chamber experiments do not proceed for a long enough duration to fully capture the processes, and these processes lead to a net increase or decrease in the volatility of the population (Hallquist et al., 2009; Cappa and Wilson, 2012; Donahue et al., 2013; Hildebrandt Ruiz et al., 2015; Jathar et al., 2016a). Second, it is likely that previous estimates of SOA yields from wellknown VOC precursors (e.g., toluene, xylene, alkanes, isoprene, terpenes) derived from smog chamber experiments were biased by unaccounted loss of semivolatile organic vapors to the chamber walls (Hildebrandt et al., 2009; Mat- 
sunaga and Ziemann, 2010; Loza et al., 2010; Yeh and Ziemann, 2014; Zhang et al., 2014, 2015; Cappa et al., 2016; Nah et al., 2016; Krechmer et al., 2016; Saha and Grieshop, 2016; Ma et al., 2017; Nah et al., 2017). The magnitude of this bias likely varies substantially among experimental systems (i.e., precursor and oxidant identity) and experimental conditions (e.g., seed concentration, relative humidity, temperature; Krechmer et al., 2016; Nah et al., 2016). Finally, aerosol liquid water may absorb soluble organic vapors and shift the partitioning to enhance OA concentrations as explored by Pye et al. (2017).

Several models have now incorporated the semivolatile POA partitioning phenomena demonstrated by Robinson et al. (2007), relying on a framework popularly referred to as the volatility basis set (VBS; Donahue et al., 2006, 2011, 2012). Examples of these models include box-scale (Dzepina et al., 2009, 2011; Hayes et al., 2015; Ma et al., 2017), regional-scale (Lane et al., 2008; Shrivastava et al., 2008; Murphy and Pandis, 2009; Tsimpidi et al., 2010; Hodzic et al., 2010; Hodzic and Jimenez, 2011; Murphy et al., 2011; Ahmadov et al., 2012; Bergstrom et al., 2012; Zhang et al., 2013; Koo et al., 2014; Matsui et al., 2014; Knote et al., 2015; Tuccella et al., 2015; Zhao et al., 2016a), and globalscale (Pye and Seinfeld, 2010; Farina et al., 2010; Jathar et al., 2011; Jo et al., 2013; Tsimpidi et al., 2014; Tsigaridis et al., 2014) applications. Each implementation has made assumptions about the emissions and SOA yields of IVOCs, the reaction rates and products of multigenerational aging, and, in some cases, the biases from chamber wall losses of semivolatile vapors. Despite wide application of the VBS framework, large-scale modeling studies, which include many other uncertainties from emissions inventories, scavenging processes, and oxidant concentrations have made slow progress towards reducing the uncertainty of the many free parameters related to OA emission, formation, and processing. However, the details of the implementation in CTMs affect OA source apportionment (Hodzic et al., 2010; Pye and Seinfeld, 2010; Murphy et al., 2012; Bergstrom et al., 2012; Matsui et al., 2014; Hodzic et al., 2014). Current implementations in global models result in a spread of 1-2 orders of magnitude in OA concentrations across models, especially aloft and in remote areas (Tsigaridis et al., 2014; Tsimpidi et al., 2017). Therefore, caution should be exercised when adopting an SOA formation mechanism that appears detailed but is largely unconstrained.

Hodzic and Jimenez (2011) showed that an optimized twoparameter fit for SOA formation from anthropogenic sources (constraining the amount and timescale of SOA formation) could successfully capture trends observed in multiple field studies (DeCarlo et al., 2010). That parameterization reasonably reproduced aerosol mass spectrometer (AMS) observations within and downwind of a megacity. The SIMPLifiEd parameterization of combustion SOA (SIMPLE) demonstrated by Hodzic and Jimenez (2011) involved one VOC surrogate which, when oxidized by hydroxyl radicals, formed one condensable vapor that partitioned irreversibly to the particle phase. The use of nonvolatile SOA as an approximation was based on the observation that real SOA had low volatility and generally much lower than used in prior models (Dzepina et al., 2009; Huffman et al., 2009b). The uncertain parameters, the emission of the VOC and its oxidation reaction rate, were optimized for performance in the regional model CHIMERE. This method was reapplied to analyze urban-scale data at Pasadena (Hayes et al., 2015). Most recently, Woody et al. (2016) applied the SIMPLE method in the Community Multiscale Air Quality model version 5.2 (CMAQv5.2) to Pasadena and showed substantially improved model-measurement agreement, while Kim et al. (2015) applied it to the SE US and showed agreement with fossil/non-fossil carbon observations.

We document here the implementation and evaluation of semivolatile partitioning of POA and addition of observed, but unspeciated, SOA in CMAQv5.2. The model approach uses the VBS framework to account for the dynamic partitioning and aging of POA emissions, without modifying the two-product approach for SOA formation from traditional SOA precursor VOCs (e.g., toluene, xylene, alkanes, isoprene, terpenes). We further introduce a new surrogate species, potential SOA from combustion emissions (pcSOA) to account for missing mass from IVOC oxidation, multigenerational aging of (anthropogenic) secondary organic vapors (from IVOC and VOC precursors), biases in SOA yields from vapor wall losses, and enhanced organic partitioning to the condensed aqueous phase. In addition to these sources, pcSOA could account for mass from oxidation of as-yet unidentified sources of SOA precursors. The contribution of this surrogate species to the total OA burden is governed by two parameters, analogous to the simple method of Hodzic and Jimenez (2011) - the emission rate of the SOA precursor and the precursor reaction rate with hydroxyl radicals. In the following sections we present a comprehensive evaluation of the improvement in CMAQ OA predictions at two horizontal resolutions ( 4 and $12 \mathrm{~km}$ ) over multiple seasons and years, using multiple gas-phase chemical mechanisms. We explore the sensitivity of CMAQ OA to two parameters directly impacting pcSOA formation and recommend important areas of future work.

\section{Organic aerosol module configuration}

In developing CMAQv5.2, we have updated the OA module to be more consistent with current understanding of POA emission and to better represent the magnitude of SOA formation from anthropogenic combustion sources.

\subsection{POA semivolatile partitioning and aging}

The model accounts explicitly for the gas-particle partitioning of primary organic compounds and their multigenera- 
Table 1. Properties of semivolatile POA species in CMAQv5.2.

\begin{tabular}{lrrrrrr}
\hline $\begin{array}{l}\text { Species name } \\
\text { (Particle/vapor) }\end{array}$ & $\begin{array}{r}\text { Molecular weight } \\
\mathrm{g} \mathrm{mol}^{-1}\end{array}$ & $\begin{array}{r}C^{*}, 1 \\
\mu \mathrm{g} \mathrm{m}^{-3}\end{array}$ & $\mathrm{~N}_{\mathrm{C}}$ & $\mathrm{O}: \mathrm{C}$ & $\begin{array}{r}\mathrm{H}_{\mathrm{vap}} \\
\mathrm{kJ} \mathrm{mol}^{-1}\end{array}$ & $\begin{array}{r}\text { POA emission } \\
\text { Fraction }^{2}\end{array}$ \\
\hline ALVPO1/VLVPO1 $^{3}$ & 218 & 0.1 & 13.0 & 0.185 & 89 & 0.09 \\
ASVPO1/VSVPO1 $^{4}$ & 230 & 1 & 14.5 & 0.123 & 85 & 0.09 \\
ASVPO2/VSVPO2 $_{\text {ASVPO3/VSVPO3 }}^{5}$ & 241 & 10 & 16.0 & 0.073 & 81 & 0.14 \\
AIVPO1/VIVPO1 $^{5}$ & 253 & 100 & 17.5 & 0.032 & 77 & 0.18 \\
ALVOO1/VLVOO1 $^{6}$ & 266 & 1000 & 19.0 & 0.00 & 73 & 0.5 \\
ALVOO2/VLVOO2 $_{\text {ASVOO1/VSVOO1 }}$ & 136 & 0.01 & 5.0 & 0.886 & 93 & $\mathrm{n} / \mathrm{a}$ \\
ASVOO2/VSVOO2 & 136 & 0.1 & 5.5 & 0.711 & 89 & $\mathrm{n} / \mathrm{a}$ \\
ASVOO3/VSVOO3 & 135 & 1 & 6.0 & 0.567 & 85 & $\mathrm{n} / \mathrm{a}$ \\
\hline
\end{tabular}

${ }^{1} C^{*}$ values are defined at reference temperature $298 \mathrm{~K} .{ }^{2}$ Robinson et al. (2007). ${ }^{3} \mathrm{~A}=$ aerosol; $\mathrm{V}=$ vapor; $\mathrm{LV}=$ low volatility; $\mathrm{PO}=$ primary organic $;{ }^{4} \mathrm{SV}=$ semivolatile; ${ }^{5} \mathrm{IV}=$ intermediate volatility; ${ }^{6} \mathrm{OO}=$ oxidized organic. $\mathrm{n} / \mathrm{a}$ : not applicable.

tional oxidation products with a range of volatility, similar to the $1.5 \mathrm{D}$ volatility basis set scheme of Koo et al. (2014). Table 1 lists the new species in the aerosol module as well as important properties. Like Koo et al. (2014), we choose surrogates with volatilities that are relevant for typical atmospheric loadings (i.e., $0.1-1000 \mu \mathrm{g} \mathrm{m}^{-3}$ ). Donahue et al. (2011) related the volatility, expressed in terms of an effective saturation concentration $C^{*}$, to both carbon number and $\mathrm{O}$ : C using structure activity relationships, vapor pressure estimation methods like SIMPOL (Pankow and Asher, 2008), and available vapor pressure measurements, and we apply their methods here (see Supplement). For the directly emitted species (LVPO1, SVPO1, SVPO2, SVPO3, and IVPO1), the carbon number $(\mathrm{C} 17-\mathrm{C} 19)$ and $\mathrm{O}: \mathrm{C}(0-0.1)$ of the new surrogate species are chosen to be consistent with laboratory and field observations of the properties of POA from combustion sources (Aiken et al., 2008; Huffman et al., 2009a; Presto et al., 2012; May et al., 2013a, b, c; Canagaratna et al., 2015). Previously, Simon and Bhave (2012) used a separate tracer, PNCOM, in CMAQ to track the contribution of noncarbon organic matter to the total POA mixture. During the emission input generation procedure, PNCOM emission factors were informed by the OM : OC (the ratio of total organic mass to organic carbon mass) of individual sources (e.g., mobile, 1.25; cooking, 1.4; biomass burning, 1.7). In the present model we sum the primary organic carbon and non-carbon emission factors in order to preserve the source-aware mass emissions developed by Simon and Bhave (2012). Because the new primary surrogate species have fixed $\mathrm{O}: \mathrm{C}$ (Table 1), the source resolution in $\mathrm{O}: \mathrm{C}$ is lost. This limitation can be overcome in future model versions by treating, for example, biomass burning OA independently with additional model species.

For the oxidation products of the directly emitted species (LVOO1, LVOO2, SVOO1, SVOO2, SVOO3), we have chosen higher OM : OC (and thus lower carbon number) values than Koo et al. (2014) to bound the typical observed range of OM : OC reported from ambient studies, including Aiken et al. (2008) and Canagaratna et al. (2015) for multiple US and global sites (1.3-2.25) and Simon et al. (2011) for routine-monitoring networks in the continental US (0.792.15). The molecular weights of these species are calculated using the given carbon number and OM : OC, while assuming each representative species comprises only carbon, oxygen, and hydrogen atoms. The $\mathrm{H}: \mathrm{C}$ is calculated from $\mathrm{O}: \mathrm{C}$ using insights from Heald et al. (2010) - a common assumption for deriving molecular weights of VBS species in chemical transport models. The species enthalpy of vaporization is assumed to be a linear function of $C^{*}$ (May et al., 2013b; Epstein et al., 2010), and the Henry's law coefficient is prescribed at $2 \times 10^{8} \mathrm{M} \mathrm{atm}^{-1}$, which is in the range reported for oxidized organic vapors by Hodzic et al. (2014) and Pye et al. (2017).

We employ one volatility distribution, from Robinson et al. (2007), for the partitioning calculation of the primary organic emissions from all combustion sources. Koo et al. (2014) found some differences in their results when they used separate distributions for biomass burning, gasoline, and diesel sources. The Robinson et al. (2007) distribution results in more aggressive POA evaporation than the sourceresolved multi-distribution parameterization. Dzepina et al. (2009) showed that the Robinson et al. (2007) parameterization resulted in POA volatility that was similar to thermodenuder observations. We performed a sensitivity simulation using a single modified distribution calculated by summing the source-resolved distributions weighted by their total emissions in the California (CAL) domain. This simulation resulted in maximum hourly POA increases of $10-15 \%$. Future work will incorporate emerging measurements of primary organic compound volatility information directly into the generation of emission inventories, along with estimating sensitivities to key factors like ambient temperature, operating conditions, and fuel type. We do not apply a scaling factor to the POA input emission factor to, for example, intro- 
duce new SVOCs to the model. Our approach assumes that existing inventory POA emission factors are actually representative of the total gas- plus particle-phase mass with saturation concentration below about $3200 \mu \mathrm{g} \mathrm{m}^{-3}$. It is unclear to what extent SVOCs are missing from the emission factors that inform current inventories as these experiments were conducted at low dilution ratios and enhanced partitioning to the particulate phase. This issue should be resolved by taking into account temperature and organic aerosol loading in past and future laboratory-scale experiments when that data are available.

Additionally, some of the semivolatile primary particle mass that evaporates condenses back to the particle phase after oxidation. Although direct observations of primary combustion-derived SVOC aging are rare, both field results (Chan et al., 2013) and their relatively large carbon numbers support that they are susceptible to $\mathrm{OH}$ oxidation and SOA formation in the atmosphere. We apply an $\mathrm{OH}$ oxidation reaction with a rate constant equal to $4.0 \times 10^{-11} \mathrm{~cm}^{3}$ molec $^{-1} \mathrm{~s}^{-1}$ to simulate this aging, consistent with previous modeling studies (Grieshop et al., 2009; Farina et al., 2010; Murphy and Pandis, 2009; Koo et al., 2014; Zhao et al., 2016a). The stoichiometric coefficients for this oxidation step are derived using 2D-VBS theory for

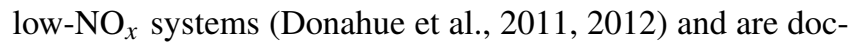
umented in supporting information. The branching ratio for functionalization and fragmentation processes is parameterized as in Eq. (1).

$\beta_{\text {frag }}=(\mathrm{O}: \mathrm{C})^{0.4}$

The aging configuration tends to produce lower volatility (thus more particulate) mass than that used by Koo et al. (2014) and produces slightly less total organic mass (OM) than the full 2D-VBS model of Chuang and Donahue (2016) (see Fig. S1a in the Supplement). The bulk O : C enhancement due to aging is more vigorous in this model compared to the full 2D VBS. However, the rate of $\mathrm{O}: \mathrm{C}$ enhancement is about half that of the POA aging scheme implemented in older CMAQ versions (Simon and Bhave, 2012) (see Fig. S1b).

\subsection{SOA from traditional precursors}

SOA formed from oxidation of traditional VOC sources (isoprene, monoterpenes, sesquiterpenes, benzene, toluene, xylene, alkanes, and PAHs) are documented in Carlton et al. (2010) and Pye and Pouliot (2012). The SOA yields of these compounds has been unchanged in the development of CMAQv5.2, although updates to their molecular properties (solubility, molecular weight, OM : OC, etc.) were incorporated to maintain consistency throughout the model processes (Pye et al., 2017). CMAQv5.2 also includes aqueous processing of isoprene epoxides, glyoxal, and methylglyoxal, as well as production of oligomeric species from particlephase reaction of traditional SOA compounds. We do not employ the recent liquid-liquid phase partitioning algorithms implemented by Pye et al. (2017).

\subsection{Potential SOA from combustion emissions}

Because the individual contributions to the total bias from missing IVOC oxidation, missing multigenerational aging of VOC oxidation products, under-representing SOA yields because of chamber wall losses, and uptake of organics by aerosol liquid water are all uncertain, we introduce one surrogate aerosol species, pcSOA, to address the total missing OA mass. Three essential features are common among the aforementioned uncertain processes: they involve emission of gas-phase compounds, some degree of photooxidation of those compounds, and condensation of the resulting products. Thus, we simulate this formation process analogously to the SIMPLE approach of Hodzic and Jimenez (2011). A new surrogate VOC species (potential VOC from combustion emissions, pcVOC) is introduced with an emission rate that is scaled to the POA mass emission rate. This species does not partition directly to the particle phase and, in that respect, behaves as a VOC in the model. It is oxidized with $\mathrm{OH}$ to form a low-volatility condensable vapor - potential secondary organic gas from combustion emissions, pcSOG (Table 2). For the BASE (base emission, base reaction) simulation we assume an $\mathrm{OH}$ reaction rate constant equal to the optimal rate constant reported by Hayes et al. (2015), and we convert the optimal emission scale factor of Hayes et al. (2015), which is scaled from $\mathrm{CO}$ emissions to one that can be applied to POA emissions. To convert from $\mathrm{g}^{-1} \mathrm{CO}$ to $\mathrm{g}^{-1} \mathrm{POA}$, we multiply by the average ratio of $\mathrm{CO}$ emissions to POA emissions in the CONUS11 (Table 3) emissions dataset, 0.82. A promising alternative to scaling emissions to POA emissions could be to apply an SOA yield directly to the oxidation of total nonmethane organic gases (NMOG), as demonstrated in Jathar et al. (2014) and implemented by Jathar et al. (2017) for vehicle emissions. Unfortunately, NMOG emissions inventory data, as they currently stand, do not always take into account the evaporation of primary vapors nor are they always treated consistently by typical emissions processing practices. We consider the implementation of semivolatile POA and missing combustion SOA in CMAQv5.2 an important step toward an even more rigorous future treatment, whether that involves scaling emissions to CO or NMOG. As such, we have prioritized minimizing the need for reprocessing emissions inputs for users of previous CMAQ versions, but this does leave room for future refinement of source-specific SOA formation from unspeciated vapor emissions.

The emissions of pcVOC are applied to all combustionrelated area and point sources of primary organic carbon except for wildfires (classified as point sources), as it has been shown that fire plumes do not exhibit an SOA enhancement as strong as those dominated by urban emissions (Cubison et al., 2011). Thus, important sources like on-road vehicles, power plants, and commercial cooking are all included. 
Table 2. Properties of potential SOA from combustion emissions (pcSOA) species and its precursor, pcVOC, for the base case (BASE) CMAQ simulation.

\begin{tabular}{ll}
\hline Property & Value \\
\hline Molecular weight & $170 \mathrm{~g} \mathrm{~mol}-1$ \\
Emissions scale factor (pcVOC/POA) & $0.0568 \mathrm{~mol} \mathrm{g-1}$ \\
OH oxidation rate constant $\left(k_{\mathrm{OH}}\right)$ & $1.25 \times 10^{-11} \mathrm{~cm}^{-3} \mathrm{molec}^{-1} \mathrm{~s}^{-1}$ \\
Condensable product saturation concentration $\left(C^{*}\right)$ & $10^{-5} \mu \mathrm{g} \mathrm{m}$ \\
\hline
\end{tabular}

Hayes et al. (2015) and Ma et al. (2017) showed that residential as well as commercial cooking sources of SOA are potentially an important contribution to non-fossil carbon in Pasadena, and residential cooking sources are missing from the inventories used here. The inclusion of both residential wood burning and agricultural burning area sources in the pcSOA parameterization should be investigated further and potentially treated separately in the future by adding more detailed online source resolution to the CMAQv5.2 OA model. The partitioning between pcSOG and pcSOA is governed by a saturation concentration equal to $1 \times 10^{-5} \mu \mathrm{g} \mathrm{m}^{-3}$. Although heterogeneous reactions are implemented for other SOA types in CMAQ, no further reactions are included for pcSOA. Additionally, photolysis leading to degradation of low-volatility material is not considered in the model (Hodzic et al., 2015). The low volatility of pcSOA makes this OA configuration behave similarly in many ways to the approach of Shrivastava et al. (2013), which attempts to account for semisolid OA behavior and oligomer formation; however, there are important differences. All OA mass (including pcSOA) is treated as an absorbing medium in our approach and pcSOA is created through direct oxidation and condensation of gas-phase species, not through a particle-phase transformation. Future work will address the role of diffusion-limited OA absorptive partitioning and its dependence on relative humidity. The emission scale factor and oxidation rate constant are uncertain parameters, and we present a sensitivity analysis of them in order to both demonstrate the relevance of this uncertainty to total OA concentrations and to recommend acceptably performing parameters for use in operational CMAQv5.2 simulations.

\section{Model application}

We apply CMAQv5.2 with the enhanced OA module to three distinct simulation domains: the continental United States, the eastern United States, and California. The time periods and chemistry options, detailed below, are chosen to leverage existing observations while also evaluating the model under various configurations. The individual simulations are summarized in Table 3.

\subsection{Observations}

In order to connect the performance of the updated model with past CMAQ versions, we evaluate predictions against organic carbon (OC) observations from routine-monitoring networks including the Interagency Monitoring of Protected Visual Environments (IMPROVE) and Chemical Speciation Network (CSN) datasets. We note that IMPROVE data had a $27 \%$ low bias relative to collocated SEARCH observations during summer 2013 in the SE US, which is thought to be due to evaporation during sampling and transport (Kim et al., 2015). That bias was not observed for non-summer samples. Additionally, we focus on three intensive measurement campaigns: the California Research at the Nexus of Air Quality and Climate Change (CalNex), the Carbonaceous Aerosols and Radiative Effects Study (CARES), and the Southern Oxidant and Aerosol Study (SOAS). At these sites, CMAQ OA predictions are evaluated against High-Resolution Time-ofFlight Aerosol Mass Spectrometer (HR-ToF-AMS) data. The Southeastern Aerosol Research Characterization (SEARCH) network sites located in the southeast US provide semicontinuous OC observations also used to evaluate model capability during the SOAS time period. Two urban sites, Jefferson Street, Atlanta, GA, and Birmingham, AL, and one rural site, Yorkville, GA, are selected. During the CARES and SOAS campaigns, thermodenuder measurements allow us to make a quantitative evaluation of the OA volatility distribution predicted by the model.

The CalNex campaign characterized atmospheric composition at two sites in southern California, Pasadena, and Bakersfield, from 15 May to 29 June 2010 (Ryerson et al., 2013). The Pasadena site was located $18 \mathrm{~km}$ northeast and generally downwind of downtown Los Angeles, while the Bakersfield site was situated at the southern end of the San Joaquin Valley (SJV). Several studies characterized OA properties and likely sources at Pasadena and the larger LA basin with observations (Washenfelder et al., 2011; Bahreini et al., 2012; Borbon et al., 2013; Hersey et al., 2013; Liu et al., 2012a; Hayes et al., 2013; Fast et al., 2014; Knote et al., 2014; Ma et al., 2017), while others combined measurements with models at multiple scales (Chan et al., 2013; Ensberg et al., 2014; Hayes et al., 2015; Baker et al., 2015; Woody et al., 2016). On average, organic compounds comprised $41 \%$ of the total $\mathrm{PM}_{1}$ mass concentrations at Pasadena and exhib- 
Table 3. CMAQ model scenarios used for this study.

\begin{tabular}{lllll}
\hline Name & Spatial domain & Duration & $\begin{array}{l}\text { Gas-phase chemical } \\
\text { mechanism }\end{array}$ & Reference \\
\hline CAL & Southwestern US & 3 May-30 Jun 2010 & CB05e51 & $\begin{array}{l}\text { Baker et al. (2015); } \\
\text { Woody et al. (2016) }\end{array}$ \\
EUS & Eastern US & 1-30 Jun 2013 & SAPRC07tic & Pye et al. (2015) \\
CONUS11 & Continental US & 1 Jan-31 Dec 2011 & CB05e51 & Appel et al. (2017) \\
CONUS02 & Continental US & 1-30 Jan; 1-31 Jul 2002 & CB05e51 & Bash et al. (2013) \\
\hline
\end{tabular}

ited a strong diurnal-averaged peak concentration in the midafternoon (15:00 local time; Hayes et al., 2013). At Bakersfield, OA compounds comprised $56 \%$ of the total $\mathrm{PM}_{1}$ mass, and fossil fuel sources were determined to contribute 80$90 \%$ of those components (Liu et al., 2012b; Gentner et al., 2014). Average $\mathrm{O}: \mathrm{C}$ at Pasadena ranged from about 0.38 to 0.48 throughout the campaign with some extreme values extending to 0.8 .

The CARES campaign took place in northern California from 2 to 28 June 2010 and conducted measurements at two ground sites, Sacramento and Cool, and from the DOE G-1 aircraft (Zaveri et al., 2012). The Cool site is a suitable location to observe interactions among anthropogenic and biogenic pollutants due to its proximity to outflow from Sacramento and the forested foothills of the Sierra Nevada mountains (Setyan et al., 2012, 2014). Like those at the CalNex stations, observations during CARES indicated that organic compounds dominated $(\sim 80 \%)$ the particle-phase mass composition at both sites (Setyan et al., 2012; Shilling et al., 2013). Shilling et al. (2013) and Setyan et al. (2012) showed that the combination of anthropogenic and biogenic pollutants in the vicinity of Sacramento could enhance SOA formation significantly beyond instances when just anthropogenic or just biogenic sources contributed.

The SOAS campaign also targeted observations of anthropogenic-biogenic interactions but at three sites (Centreville, AL; Birmingham, AL; and Look Rock, TN) in the substantially differing southeastern US environment during June and July 2013 (Carlton et al., 2016). Anthropogenic emissions, including $\mathrm{NO}_{x}$ and $\mathrm{SO}_{2}$, have large influence on isoprene and monoterpene SOA in both rural and urban platforms (Budisulistiorini et al., 2015; Hu et al., 2015; Xu et al., 2015; Rattanavaraha et al., 2016). Pye et al. (2015) and $\mathrm{Xu}$ et al. (2015) found that organic nitrate chemistry likely played a substantial role in the formation of observed lessoxidized oxygenated OA (LO-OOA) compounds at the Centreville site. $\mathrm{Xu}$ et al. (2015) also found that SOA from isoprene oxidation contributed $18 \%$ of the total OA averaged throughout the campaign.

\subsection{Model configuration and analysis}

We configured CMAQv5.2 to simulate air quality over California at a horizontal resolution of $4 \mathrm{~km}$ by $4 \mathrm{~km}$ during May and June 2010. The input parameters are documented extensively by Baker et al. (2013), Baker et al. (2015), and Woody et al. (2016) and are summarized briefly here. Meteorological inputs are generated using the Weather Research and Forecasting Model (WRF) Advanced Research WRF core version 3.1 (Skamarock et al., 2008). Baker et al. (2013) evaluated the meteorological parameters (temperature, wind speed, wind direction, etc.) and found acceptable performance. The boundary conditions were generated from running a coarser resolution CMAQ simulation from December 2009 through June 2010. That coarse simulation used boundaries driven by a GEOS-Chem (v8-03-02) simulation from the same period (Henderson et al., 2014). Electrical generating unit and other point source emissions were estimated specifically for 2010 using continuous emissions monitoring data. Mobile source emissions were generated using a combined approach of generation by the SMOKE-MOVES integration platform (US Environmental Protection Agency, 2014) and projection by the California Air Resources Board. Other anthropogenic emissions are based on the $2011 \mathrm{Na}$ tional Emissions Inventory (NEI) version 1 (US Environmental Protection Agency, 2014). Day-specific fire emissions are incorporated into the model inputs, although they do not impact concentrations in Pasadena to a large extent (Hayes et al., 2013). Setyan et al. (2012) and Shilling et al. (2013) also found low impact from biomass burning at both CARES sites. Residential meat-cooking emissions are not included in the emissions inventory as pointed out by Woody et al. (2016). That study found that CMAQ underpredicted cooking-influenced OA by a factor of 2-4, depending on the time of day and assumptions about the volatility of meat-cooking emissions. Biogenic vapor emissions are generated by the Biogenic Emission Inventory System (BEIS) v3.14 (Carlton and Baker, 2011). A modified version of Carbon Bond 5 (CB05e51) simulated gas-phase chemical kinetics including ozone formation/destruction and OA formation among other processes.

The SOAS campaign was addressed with a second simulation over the eastern United States during June 2013 at $12 \mathrm{~km}$ by $12 \mathrm{~km}$ horizontal resolution. The WRF core model version 3.6.1 was applied for meteorological inputs, and boundary conditions were obtained from a $36 \mathrm{~km}$ by $36 \mathrm{~km}$ CMAQ simulation using boundary conditions informed by GEOS- 
Chem (Henderson et al., 2014). As explained by Pye et al. (2015) and Pye et al. (2017), anthropogenic emissions were based on the Environmental Protection Agency (EPA) National Emissions Inventory $2011 \mathrm{v} 1$, and biogenic emissions were obtained from BEIS v3.6.1. This implementation included enhanced detail in the formation of isoprene SOA and organic nitrate kinetics and partitioning. Fire emissions were based on the latest version of the Satellite Mapping Automated Reanalysis Tool for Fire Incident Reconciliation system (SMARTFIRE, www.airfire.org/smartfire/). The Statewide Air Pollution Research Center (SAPRC07) mechanism was used to predict gas-phase chemistry.

In order to extend results further, we perform a suite of simulations over the continental United States at $12 \mathrm{~km}$ by $12 \mathrm{~km}$ horizontal resolution for the entire year 2011 (CONUS11), thereby probing seasonal differences in model performance. Year-to-year variability is assessed with additional runs over the continental US during January and July 2002 (CONUS02). Anthropogenic, biogenic, and dayspecific fire emissions for the CONUS simulations are documented by Appel et al. (2017). The CONUS02 meteorological inputs were generated by WRF version 3.1, and anthropogenic emissions were derived from the 2002 NEI (Bash et al., 2013). The OA boundary conditions are downscaled from GEOS-Chem simulations, and we prescribe an $\mathrm{OM}$ : OC for these compounds equal to 2.0. We estimated organic carbon, which was measured at each site, from the model output by taking into account the species-dependent $\mathrm{O}: \mathrm{C}$ and calculating an $\mathrm{OM}: \mathrm{OC}$ using the approach of $\mathrm{Si}-$ mon and Bhave (2012).

To probe sensitivity to the uncertain pcVOC emission scale factor and oxidation rate constant, we explore a series of perturbation runs varying both of these parameters (Table 4). The parameter combinations are chosen to bound acceptably performing estimates of the parameters at Pasadena (Hayes et al., 2015). We convert the perturbed pcVOC emissions scale factors from $\mathrm{g}^{-1} \mathrm{CO}$ to $\mathrm{g}^{-1} \mathrm{POA}$ with the same conversion factor used for the BASE simulation. In addition to these sensitivity cases, we run a case that uses the same OA module configuration as CMAQv5.1 (nvPOA). Specifically, the nvPOA case includes nonvolatile POA aging consistent with Simon and Bhave (2012) and SOA formation from traditional VOC precursors. No pcSOA is implemented for the nvPOA case. We apply all of these cases to the CAL domain and to both January and July of the CONUS11 domain. Meanwhile, due to computation time constraints, we only examine the BASE case, the best-performing CONUS11 case (low emission, base reaction; LEBR), and the nvPOA case for the other months of 2011 and for the EUS and CONUS02 domains.

For semi-quantitative evaluations generally within individual or among similar datasets, we utilize standard statistical metrics to characterize model performance. These metrics include the mean bias (MB; $\mu \mathrm{g} \mathrm{m}^{-3}$ ), mean normalized error (MNE), and correlation coefficient $(r)$. For more rigorous quantitative analysis, we employ the normalized mean bias factor (NMBF, Eq. 2) and normalized mean absolute error factor (NMEF, Eq. 3) developed by Yu et al. (2006).

$\mathrm{NMBF}=S\left[\exp \left(\left|\ln \frac{\sum M_{i}}{\sum O_{i}}\right|\right)\right]-1$,

$\mathrm{NMEF}=\frac{\sum\left|M_{i}-O_{i}\right|}{\left(\sum O_{i}\right)^{[1+S] / 2}\left(\sum M_{i}\right)^{[1-S] / 2}}$,

where $M$ are model predictions, $O$ are observations, and $S=(\bar{M}-\bar{O}) /|\bar{M}-\bar{O}|$. These metrics were specifically designed to address biases that arise from comparing datasets with substantially different mean values (e.g., urban and rural locations) and widely varying degrees of over- and underprediction. If NMBF is positive (e.g., 0.6), then the model overestimates the observations by a factor of $1+\mathrm{NMBF}$ (1.6), on average. If NMBF is negative (e.g., -0.6), the model underestimates the observations by a factor of $1-\mathrm{NMBF}$ (1.6), on average. The NMEF is interpreted as follows: if $\mathrm{NMEF}=1.8$, then the model gross error is 1.8 times the mean observation for overprediction or 1.8 times the mean model prediction for underprediction, on average.

\section{Results and discussion}

\subsection{Evaluation against continuous OA mass observations}

CMAQv5.2 with semivolatile POA and pcSOA (BASE) successfully captured the day-night OA variability substantially better than the model with nonvolatile POA (nvPOA) (Fig. 1). Across all sites, improved predictions were due directly to both the volatilization of primary emissions in the morning and night and to the increased role of secondary formation via pcSOA in the afternoon. We expect these two phenomena to play the largest role in urban locations, like Los Angeles, with high combustion emissions and active photochemistry. At Pasadena, the daytime MB improved from -5.62 to -2.42 from the nvPOA to the BASE case, consistent with Woody et al. (2016), while the correlation improved from 0.67 to 0.79 . The remaining underprediction is qualitatively consistent with Ensberg et al. (2014), who concluded that current estimates of SOA mass from gasoline and diesel emissions cannot produce the SOA observed in Pasadena if unaccounted-for non-vehicular sources contribute heavily to the pool of SOA precursors. Positive matrix factorization (PMF) analysis of the observed OA into surrogate components revealed the strong influence of semivolatile oxygenated organic aerosol (SV-OOA, dominated by compounds emitted locally) in generating the afternoon OA loadings Hayes et al. (2015). The pcSOA approach reproduced this buildup of daytime urban SOA much closer than the nvPOA case. 
Table 4. Details of base and sensitivity simulation exploring pcSOA formation parameters.

\begin{tabular}{lrll}
\hline Simulation & $\begin{array}{r}\text { pcVOC emission scale } \\
\text { factor }\left(\mathrm{mol} \mathrm{g}^{-1}\right)\end{array}$ & $\begin{array}{l}k_{\mathrm{OH}} \\
\left(\mathrm{cm}^{-3} \mathrm{molec}^{-1} \mathrm{~s}^{-1}\right)\end{array}$ & Model domains \\
\hline Nonvolatile POA (nvPOA) & $\mathrm{n} / \mathrm{a}$ & $\mathrm{n} / \mathrm{a}$ & CAL, EUS, CONUS11, CONUS02 \\
Base emission, base reaction (BASE) & 0.0568 & $1.25 \times 10^{-11}$ & CAL, EUS, CONUS11 (Jan, Jul) \\
Low emission, base reaction (LEBR) & 0.0387 & $1.25 \times 10^{-11}$ & CAL, EUS, CONUS11, CONUS02 \\
High emission, base reaction (HEBR) & 0.07 & $1.25 \times 10^{-11}$ & CAL, CONUS11 (Jan, Jul) \\
Base emission, low reaction (BELR) & 0.0568 & $1.0 \times 10^{-11}$ & CAL, CONUS11 (Jan, Jul) \\
Base emission, high reaction (BEHR) & 0.0568 & $2.0 \times 10^{-11}$ & CAL, CONUS11 (Jan, Jul) \\
Low emission, high reaction (LEHR) & 0.0387 & $2.0 \times 10^{-11}$ & CAL, CONUS11 (Jan, Jul) \\
High emission, low reaction (HELR) & 0.07 & $1.0 \times 10^{-11}$ & CAL, CONUS11 (Jan, Jul) \\
\hline
\end{tabular}

n/a: not applicable.

The BASE case performed similarly to the nvPOA case in Pasadena at night. There, the PMF analysis indicated that the low-volatility oxygenated organic aerosol (LV-OOA) surrogate dominated with roughly constant diurnal-averaged concentrations $\left(\sim 2 \mu \mathrm{g} \mathrm{m}^{-3}\right.$; Hayes et al., 2015). LV-OOA had a significant contribution from regional (nonurban) biogenic OA. Other OA components such as hydrocarbonlike OA (HOA), cooking-influenced OA (CIOA), and locally sourced OA (LOA) contributed less throughout the day $\left(\sim 0.5-1 \mu \mathrm{g} \mathrm{m}^{-3}\right)$, although the concentrations of CIOA were elevated at night. The lack of significant observed OA growth at night-early morning and the lack of observed correlation between aerosol liquid water content and the fraction of condensed water-soluble organic compounds indicated a less important role of nighttime chemistry due to nitrate radicals or aqueous phase uptake (Hayes et al., 2013; Zhang et al., 2012).

Aggregate daytime predictions at the Bakersfield site improved dramatically as well (Fig. 1). Bulk factor analysis of AMS and Fourier-transform infrared spectroscopy (FTIR) observations indicated five principal $\mathrm{PM}_{1}$ source categories including aromatic SOA (24\%), alkane SOA (41\%), OA formed at night $(10 \%)$, SOA from petroleum operations $(14 \%)$, and vegetative detritus (10\%). Multiple studies have characterized the importance of organic nitrates for nighttime SOA composition at the site (Liu et al., 2012b; Rollins et al., 2012; O’Brien et al., 2013), while daytime OA formation appears to be driven by oxidation of primary vapors followed by condensation (Zhao et al., 2013). Baker et al. (2015) showed that CMAQv5.0.2 with nonvolatile POA underpredicted $\mathrm{PM}_{2.5}$ organic carbon concentrations at both Pasadena and Bakersfield, with fractional biases (FB) of -53 and $-144 \%$, respectively, generally consistent with results from CMAQv5.2 with nonvolatile POA (FB of -76 and $-79 \%$, respectively).

The BASE case underpredicted concentrations at Bakersfield at night, and this was partially due to missing particlephase organic nitrate compounds (Rollins et al., 2012) that are not formed in the gas phase by the CB05e51 mecha- nism used in the CAL simulation (see Fig. S4). Amine compounds contributed about $10 \%$ or less of OA at Bakersfield (Liu et al., 2012b) and Pasadena (Hayes et al., 2013); these are missing from the particle-phase representation in this version of CMAQ as well. The day-night trends are consistent with the results of WRF-Chem application to the same campaign Fast et al. (2014). Differences that emerge include a stronger OA daytime peak predicted by CMAQ at Pasadena and higher nighttime concentrations predicted by WRF-Chem at Bakersfield. These differences may have resulted from the use of slightly different anthropogenic emission inventories and selection of different modules for planetary boundary layer dynamics.

At Sacramento, the nvPOA case predicted significantly higher total OA concentrations at night $\left(\mathrm{MB}=0.48 \mu \mathrm{g} \mathrm{m}^{-3}\right)$ than during the day $\left(\mathrm{MB}=-1.13 \mu \mathrm{g} \mathrm{m}^{-3}\right)$, while the BASE model agreed better with observations (nighttime $\mathrm{MB}=-0.35$; daytime $=-0.41 \mu \mathrm{g} \mathrm{m}^{-3}$ ). The magnitude of the day-night performance for the rural Cool site was encouraging ( $\mathrm{MB}=-0.46$ and -0.05 , respectively), as was the correlation ( $r=0.74$ and 0.63 , respectively). Setyan et al. (2012) isolated three factors using PMF analysis at Cool, including hydrocarbon-like organic aerosol (9\% of total OA), a less-oxidized oxygenated OA $(50.3 \%)$ that peaked in the early evening, and a more-oxidized oxygenated OA (MOOOA, $40.7 \%$ ) that stayed relatively constant throughout the day with slightly elevated concentrations at night. The authors concluded that the LO-OOA was correlated with urban transport while the MO-OOA was likely influenced by biogenic VOC oxidation. The fact that about $60 \%$ of the total OA mass was related to urban sources helps explain why the introduction of POA partitioning and pcSOA mass in CMAQ would make a difference to predictions at the Cool site, in the absence of regional fire events. As urban plumes move downwind, pcSOA and POA aging in the BASE case replace most of the evaporated POA and may add extra mass to the total OA burden. For example, the additional anthropogenic OA mass improved model performance at the Cool site, which is 


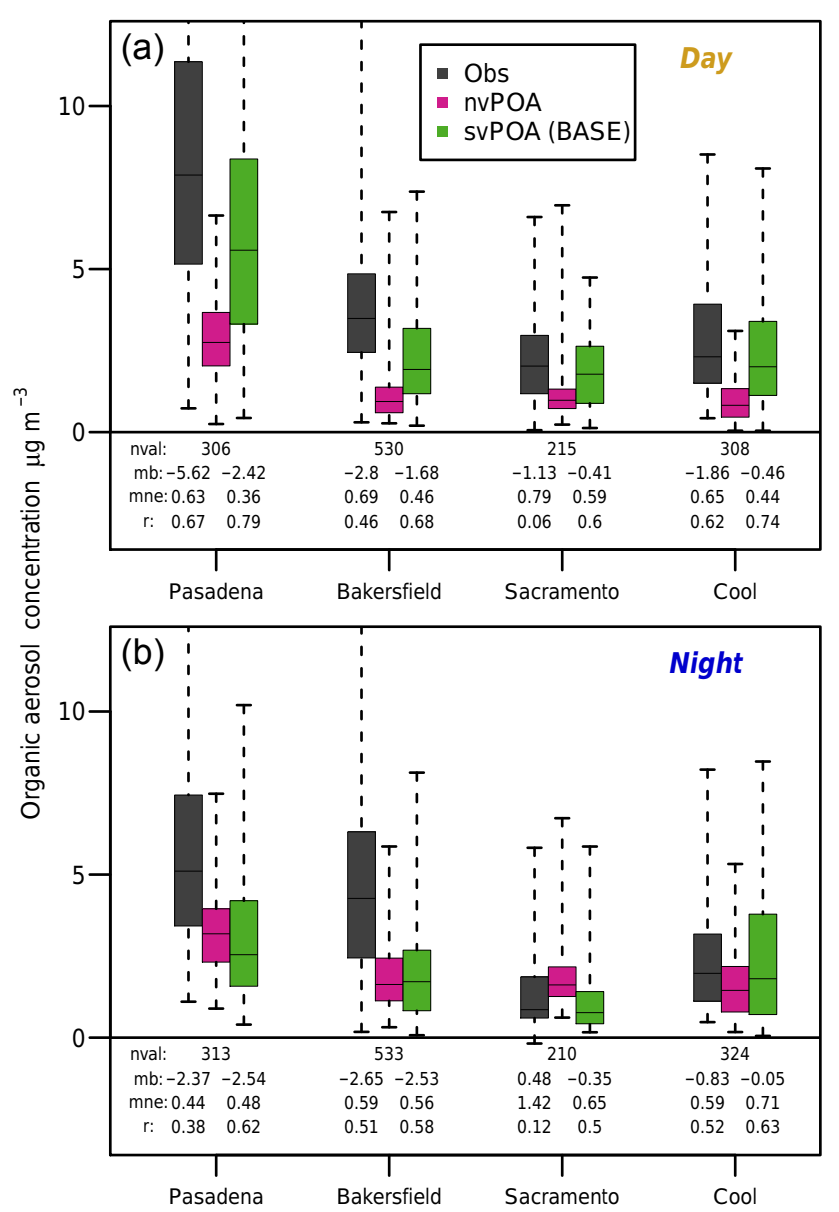

Figure 1. Organic aerosol concentrations $\left(\mu \mathrm{g} \mathrm{m}^{-3}\right)$ observed (gray) with the HR-ToF-AMS at sites in California in 2010 (Pasadena, Bakersfield, Sacramento, and Cool). Also shown are the modelpredicted distributions at each site using the nonvolatile (pink) and base-case semivolatile (green) configurations. The boxes denote the 25th and 75th percentiles of each dataset, while the whiskers extend to the most extreme points. (a) and (b) show data for daytime (08:00-20:00 LT) and nighttime hours, respectively. Model values are projected to $\mathrm{PM}_{1}$ to correspond roughly to the size cutoff of the AMS.

often directly downwind of Sacramento, but had less impact on the rural Centreville, AL, site (see Fig. S4).

The BASE case, run for the EUS domain (Fig. 2), significantly underpredicted observations at both Centreville, Look Rock, and Yorkville (daytime $\mathrm{MB}=-2.42,-3.39$, and $-0.66 \mu \mathrm{g} \mathrm{m}^{-3}$, respectively) although the OA update does improve predictions slightly compared to the nvPOA case (daytime $\mathrm{MB}=-2.72,-3.78$, and $-1.16 \mu \mathrm{g} \mathrm{m}^{-3}$, respectively). Correlation coefficients improved at all locations during both day and night, with one exception at Centreville during night. Biogenic SOA was the main OA component during SOAS (Xu et al., 2015), and CMAQv5.2 potentially under-represents these compounds due to uncertainties in $\mathrm{NO}_{x}$-dependence, oxidant loadings, and missing organic-
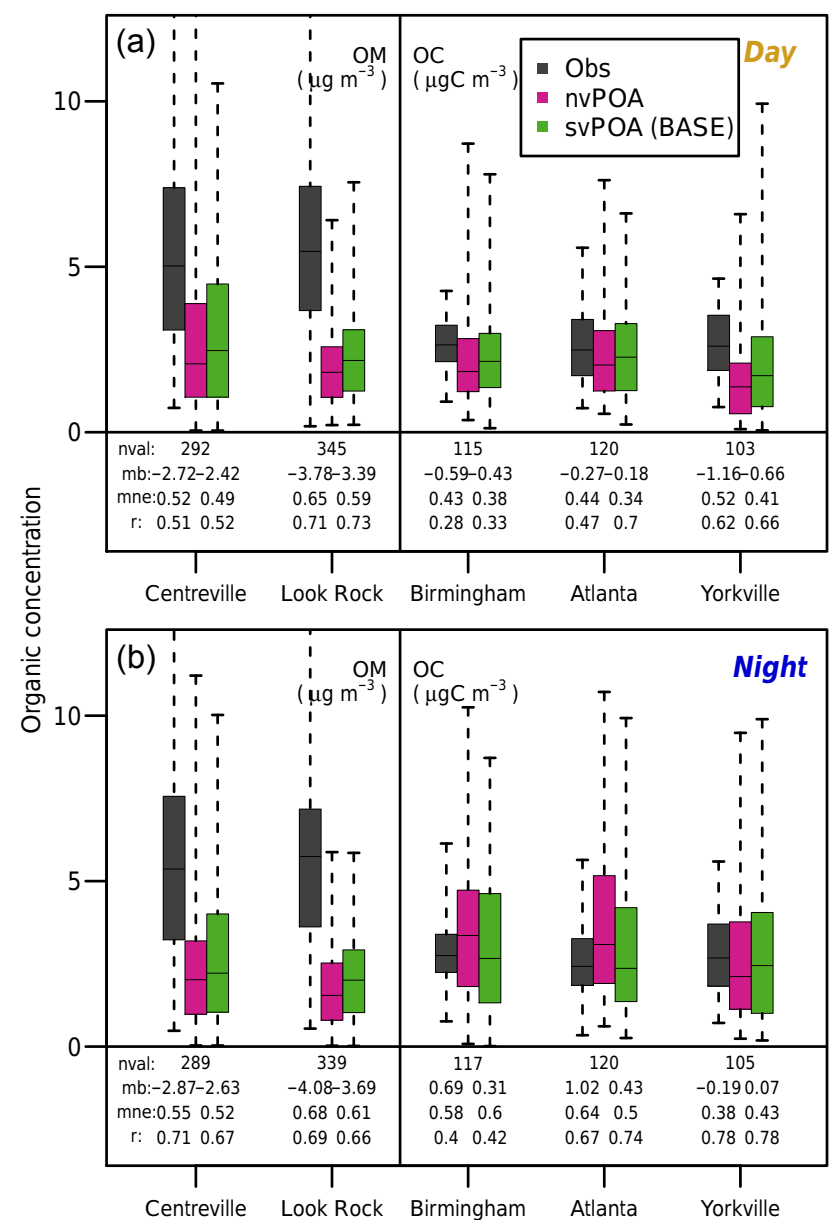

Figure 2. Observed (gray) and modeled (pink, green) organic aerosol $\left(\mu \mathrm{g} \mathrm{m}^{-3}\right)$ and organic carbon $\left(\mu \mathrm{gC} \mathrm{m}^{-3}\right)$ concentrations at sites in the southeast US. OA concentrations at the SOAS sites, Centreville and Look Rock, were measured with HR-ToF-AMS, while OC concentrations at the SEARCH sites, Birmingham, Atlanta, and Yorkville were inferred as the difference between total carbon measured by ambient particulate carbon monitors and elemental carbon measured by aethalometers. Also shown are the modelpredicted distributions at each site using the nonvolatile (pink) and base-case semivolatile (green) configurations. The boxes denote the 25 th and 75 th percentiles of each dataset, while the whiskers extend to the most extreme points. (a) and (b) show data for daytime (08:00-20:00) and nighttime hours, respectively. Model values for the SOAS sites are projected to $\mathrm{PM}_{1}$ to correspond roughly to the size cutoff of the AMS, while for the SEARCH sites the sum of the Aitken and accumulation modes was applied. All model data are produced from the EUS simulation, which uses SAPRC07tic and occurs during June 2013.

water interactions (Pye et al., 2017), as they are not yet included in this version of the model. Although previous studies have demonstrated vapor wall losses to have a relatively small effect on SOA formation from $\alpha$-pinene ozonolysis (Nah et al., 2016; McVay et al., 2016) and $\beta$-pinene oxidation by nitrate radicals (Boyd et al., 2015), it is unclear 
to what extent vapor losses may influence SOA yields from other monoterpene and sesquiterpene precursors or from reaction with $\mathrm{OH}$. Further studies on vapor wall losses are necessary. The BASE case predicts that the composition of total OA at Centreville was $65 \%$ biogenic SOA, $30 \%$ combustion SOA, and $5 \%$ POA. A prior simulation using GEOS-Chem and a similar implementation of the SIMPLE parameterization for urban and biomass burning SOA identified a contribution of $28 \%$ of the OA from urban sources, which was consistent with the fossil fraction of the carbon at the Centreville site (Kim et al., 2015). Predictions from the BASE model are similar, especially since combustion SOA and POA are from both anthropogenic and biomass burning combustion sources. The model predictions for the EUS domain include semi-explicit treatments of isoprene SOA (Pye et al., 2013) and terpene nitrate SOA formation (Pye et al., 2015), following the approach of Pye et al. (2017).

The inclusion of semivolatile POA and pcSOA did not lead to much change in southeastern US urban centers, Birmingham and Atlanta (see Fig. S4), but there was improvement at night in both locations (MB reductions of $\sim 50 \%$ ). Pye et al. (2017) estimated that primary organic carbon was overpredicted by a factor of 1.8 in the southeast US, thereby compensating for the underestimated SOA in that study.

Figure 3 compares CMAQ OA species to AMS factors derived from PMF analysis at Pasadena, Bakersfield, and Cool. PMF analysis was not available at the Sacramento site, and the Centreville and Look Rock sites showed negligible presence of HOA throughout the SOAS campaign. For the nvPOA case, POA was calculated as the sum of CMAQ species POC and PNCOM and evaluated against observed HOA, even though some fraction of the material is aged. Simon and Bhave (2012) showed that this aging is predicted to add a modest amount of non-carbon mass to POA in California ( $\sim 20 \%$ or less). For the BASE case, POA was summed from the fresh primary organic emissions (LVPO1, SVPO1, SVPO2, SVPO3, and IVPO1) and evaluated against HOA. This model-observation comparison clearly indicates, as many past studies have, that most OA, even in urban areas is partially or heavily oxygenated and that models using an approach like the nvPOA case replace OA formed by secondary processing with primary emissions. Thus, those models get an approximately correct estimate of OA concentrations for the wrong reasons and often with the wrong diurnal profile (see Sect. 4.2; De Gouw and Jimenez, 2009). At Pasadena, the nvPOA case overestimated HOA concentrations by a factor of 2.0. Treating the POA as semivolatile in the model resolved this discrepancy by reducing the predicted HOA factor. The combination of primary vapor aging and introduction of pcSOA resolved the OOA underprediction (MB improved from -4.45 to $-0.81 \mu \mathrm{g} \mathrm{m}^{-3}$ ). Figure 3 shows similar results at Bakersfield and Cool: average HOA predictions were reduced dramatically from the nvPOA to BASE case, while OOA predictions increased but still underpredicted observations by -1.3 and $-0.28 \mu \mathrm{g} \mathrm{m}^{-3}$. The un-
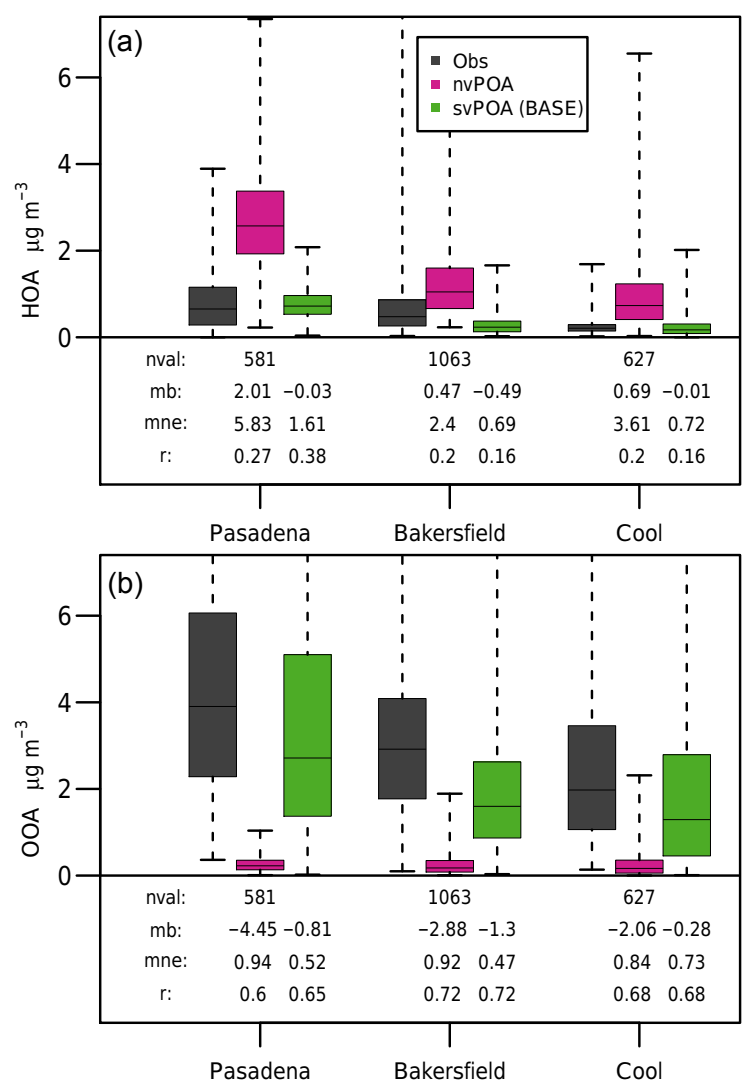

Figure 3. Comparison of OA factors derived from positive matrix factorization (PMF) of HR-ToF-AMS observations (gray) at sites in California (Pasadena, Bakersfield, and Cool). Also shown are the model-predicted concentrations of each factor at each site using the nonvolatile (pink) and base-case semivolatile (green) configurations. (a) compares estimations for hydrocarbon-like OA (HOA) and (b) for oxygenated OA (OOA). The boxes denote the 25 th and 75th percentiles of each dataset, while the whiskers extend to the most extreme points.

derprediction disappears if the HOA- and OOA-observed and predicted concentrations are normalized by the $\mathrm{CO}$ enhancement ( $\Delta \mathrm{CO}$; see Fig. S2). Because normalizing by $\Delta \mathrm{CO}$ reduces the influence of errors in transport and dilution, this metric better isolates the performance of the specific chemical and microphysical processes under investigation here. However, confidence in CO model performance from CMAQ is uncertain and should be evaluated regularly and in greater detail in the future. Baker et al. (2015) and Woody et al. (2016) noted that the CO concentrations predicted by CMAQ during CalNex were systematically 10-30\% lower, and potentially emblematic of a general limitation of CMAQ capabilities for $\mathrm{CO}$ prediction.

Both Hayes et al. (2013) and Woody et al. (2016) used the slope of OOA as a function of odd oxygen $\left(\mathrm{O}_{x}=\mathrm{O}_{3}+\mathrm{NO}_{2}\right)$ as an indicator of how well the model captured the general magnitude for urban SOA formation and its dependence on available oxidants. Hayes et al. (2013) found this slope at 
Pasadena to be $146 \mu \mathrm{g} \mathrm{m}^{-3} \mathrm{ppbv}^{-1}$, which is more consistent with the BASE model prediction $\left(103 \mu \mathrm{g} \mathrm{m}^{-3} \mathrm{ppbv}^{-1}\right)$ than with the nvPOA model $\left(7 \mu \mathrm{g} \mathrm{m}^{-3} \mathrm{ppbv}^{-1}\right)$. While the BASE model does better in capturing urban OOA, it still underpredicts its magnitude of OOA formation by $35 \%$ according to this metric. The underprediction appears more pronounced at the highest $\mathrm{O}_{x}$ levels, according to Fig. 4. Woody et al. (2016) found similar improvement in this metric when applying a version of CMAQ that explicitly included aging of first-generation anthropogenic OOA (slope equal to $72 \mu \mathrm{g} \mathrm{m}^{-3} \mathrm{ppbv}^{-1}$ ). They noted that CMAQ predictions could match the observed slope well if reactive anthropogenic SOA precursor vapors were added to account for missing SVOCs and IVOCs. It is not surprising that the BASE model performance falls between these two cases since the pcSOA model species was designed to account for these and other uncertain SOA formation processes. Model performance between the nvPOA and BASE cases improves similarly at Bakersfield $\left(m_{\mathrm{obs}}=\right.$ $80 \mu \mathrm{g} \mathrm{m}^{-3} \mathrm{ppbv}^{-1}, m_{\text {svPOA }}=54 \mu \mathrm{g} \mathrm{m}^{-3} \mathrm{ppbv}^{-1}$ ) and Cool $\left(m_{\mathrm{obs}}=75 \mu \mathrm{g} \mathrm{m}^{-3} \mathrm{ppbv}^{-1}, \quad m_{\mathrm{svPOA}}=64 \mu \mathrm{g} \mathrm{m}^{-3} \mathrm{ppbv}^{-1}\right)$. As with the HOA-OOA comparison, normalizing by $\Delta \mathrm{CO}$ improves the model performance even further, possibly canceling errors in meteorological phenomena and dispersion processes (see Fig. S3). Because CO performance is uncertain in CMAQ as previously stated, a detailed examination of the sensitivity to the pcVOC emission scale factor and $\mathrm{OH}$ reaction rate constant is useful.

\subsection{Model sensitivity to uncertain pcSOA parameters}

Figure 5 shows diurnal-averaged profiles for the observations and several model cases including nvPOA, BASE, HEBR (high emission, base reaction), and LEBR. The cases with pcSOA captured the variability throughout the day, including the timing of the afternoon OA peak, and the day-today variability, at all California sites better than the nvPOA case. At Pasadena, the mean bias improved from -4.01 to $-2.48 \mu \mathrm{g} \mathrm{m}^{-3}$ and the correlation coefficient increased from 0.15 to 0.81 . Performance at Sacramento was particularly improved in the BASE case $(\mathrm{MNE}=0.24, r=0.91)$. The pcVOC emission scale factors for HEBR and LEBR were set to the upper and lower bounds of the optimal parameter set reported by Hayes et al. (2015). The HEBR case predicted the magnitude of the afternoon OA peak at Bakersfield, Sacramento, and Cool but still underpredicted the peak at Pasadena. However, that underprediction is consistent with the underprediction at night and so may be a result of missing nighttime sources or processes. The effect of perturbing pcVOC emissions on concentrations at Centreville and Look Rock was more subdued. At those sites, pcSOA contributed 24 and $36 \%$ to the total OA mass in the $\mathrm{PM}_{1}$ range, respectively, in the BASE case. Generally, pcSOA concentrations were reduced by $30 \%$ when the LEBR parameters were employed. Accounting for the pcSOA reduction and the effect
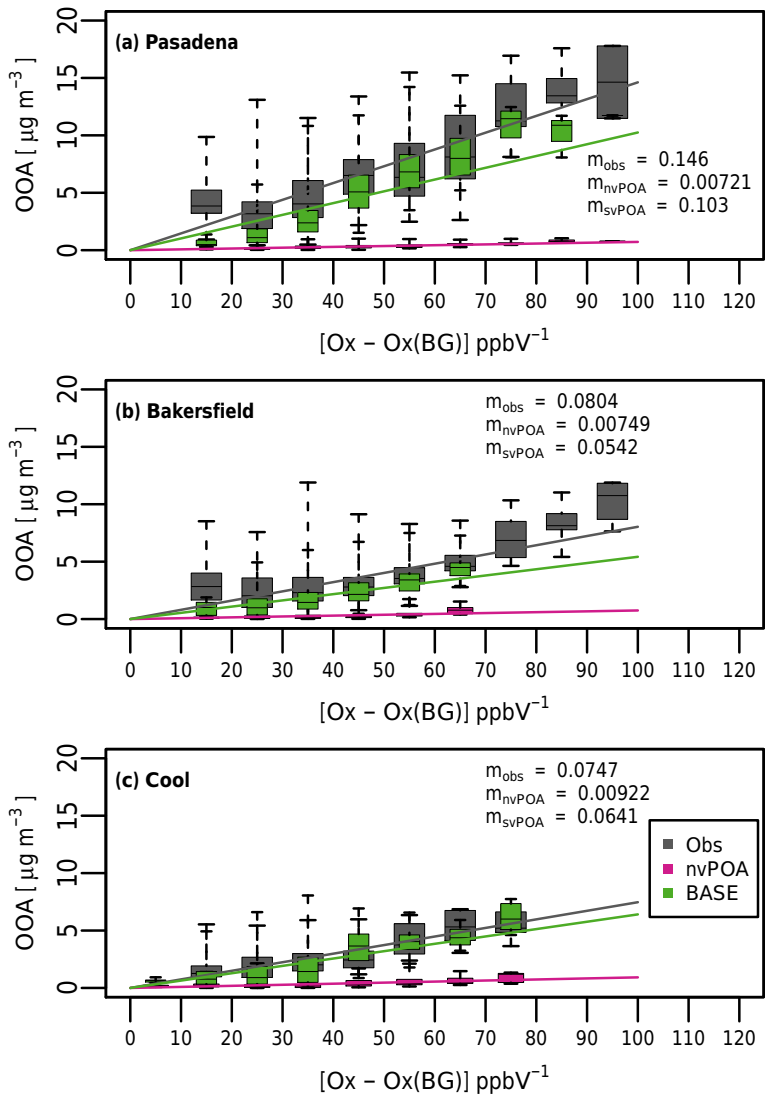

Figure 4. OOA concentrations $\left(\mu \mathrm{g} \mathrm{m}^{-3}\right)$ at California sites as a function of the measured $\mathrm{O}_{x}\left(\mathrm{O}_{3}+\mathrm{NO}_{2}\right)$ concentration. A background concentration, $\mathrm{O}_{x}(\mathrm{BG})$, of $13.5 \mathrm{ppbv}$ is assumed, consistent with Hayes et al. (2015). The boxes behind each trend indicate the 25 th and 75 th percentiles of the data. The whiskers extend to the 10th and 90th percentiles. The solid horizontal lines in each box identify the median, and the solid curves indicate the means of each model run. Model values are projected to $\mathrm{PM}_{1}$ to correspond roughly to the size cutoff of the AMS.

of decreased total-OA-absorbing media on other OA surrogates resulted in a $13 \%$ decrease in $\mathrm{OA} \mathrm{PM}_{1}$ concentrations.

We then varied both of the pcSOA parameters in the BASE model configuration as described in Table 4 to quantify the sensitivity of model predictions holistically. Figure 6 shows the NMBF and NMEF metrics calculated for each combination of input parameters investigated as well as those of the nvPOA run. These factors were computed for model-observation pairs grouped by each station individually and then averaged together. The conclusions of this analysis did not change when these metrics were calculated for all the pairs without grouping into sites first. When comparing against continuous data collected during CalNex and CARES, the nvPOA case performed worse than every sensitivity case for both metrics. For NMBF, the optimal emission factor likely lies between the base and high values, as long as the appropriate $\mathrm{OH}$ reaction rate is chosen to constrain 

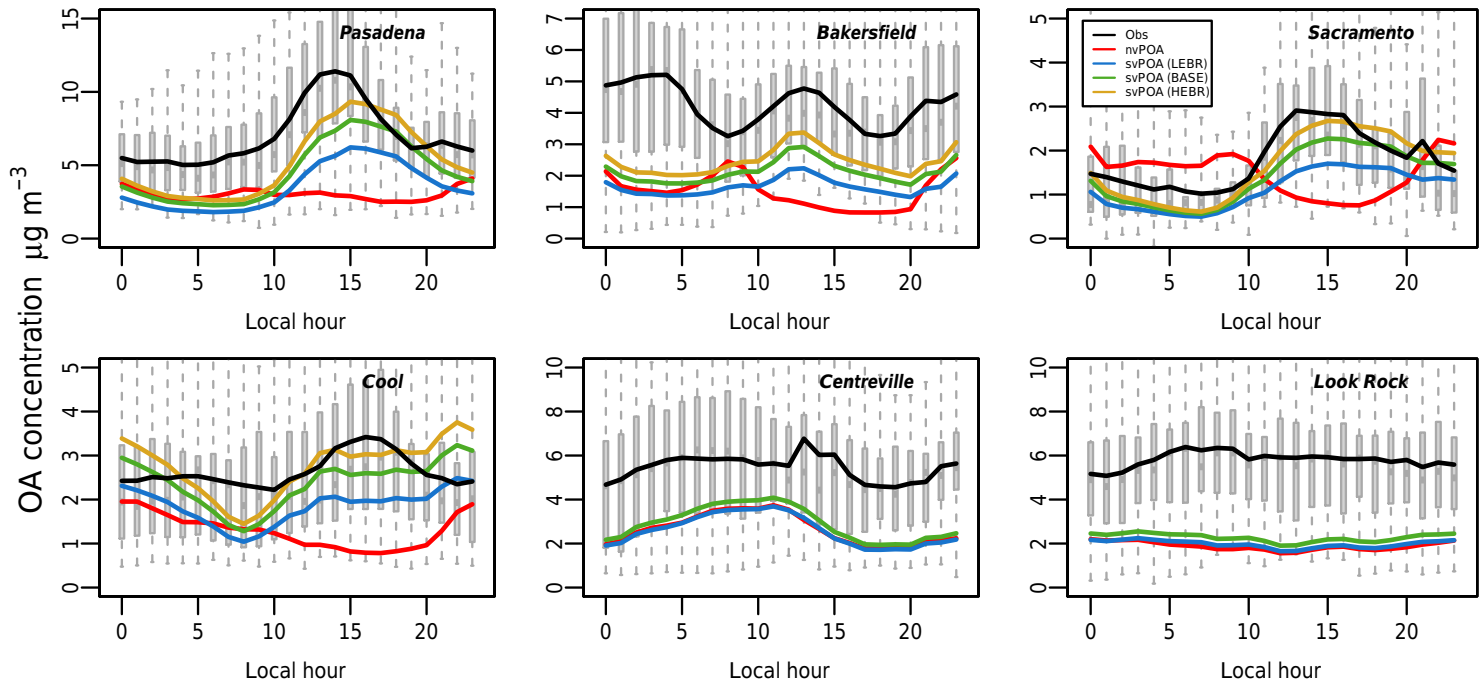

Figure 5. Diurnal OA concentration profile $\left(\mu \mathrm{g} \mathrm{m}^{-3}\right)$ observed (black line, gray bars) with the HR-ToF-AMS at sites investigated during the CalNex, CARES, and SOAS campaigns. Also shown are the model-predicted distributions for the nvPOA case, the BASE case, and two sensitivity cases (LEBR and HEBR). The boxes behind each trend indicate the 25th and 75th percentiles of the data. The whiskers extend to the 10th and 90th percentiles. The solid horizontal lines in each box identify the median, and the solid curves indicate the means of each model run. Model values are projected to $\mathrm{PM}_{1}$ to correspond roughly to the size cutoff of the AMS.

the total mass formed. It is not clear whether the parameter space explored constrained the NMEF values, although they may possibly plateau at 0.48 as one moves up and to the right on Fig. 6. These findings are consistent with those of Hayes et al. (2015), although that analysis parameterized the VOC precursor emissions to the emission of $\mathrm{CO}$ rather than POA. The emission factor used here avoids the potentially problematic $\mathrm{CO}$ model predictions by relying on the more robust POA emission rate as an indicator. An area of future work will be to develop the capability to use total VOC emissions from all combustion sources as the basis for pcVOC emissions since they should be even more correlated.

Evaluations of NMBF and NMEF for the CONUS11 simulations (Fig. 7) result in different optimal pcSOA parameters. Daily averaged model predictions are paired with observations at sites from both the IMPROVE and CSN networks for January and July 2011. For this application, the nvPOA case results in a lower NMEF (0.83) than half of the sensitivity cases, which are those with emission factors or reaction rates higher than those of the BASE model $(\mathrm{NMEF}=0.82)$. Further, the nvPOA case has a lower NMBF (0.39) than all cases but the LEBR case (0.27). The parameter space is unbounded here, and even lower emission factor-reaction rate combinations could potentially reduce the NMBF and NMEF, but those solutions are not supported by the analysis for the CAL domain. The need for higher emissions or reaction rates to support higher OA concentrations at the California sites is not corroborated by the CONUS11 data, indicating that differences in the sources or production pathways that drive OA concentrations at these two scales are not completely captured with the uniform application of pcSOA. In the east-
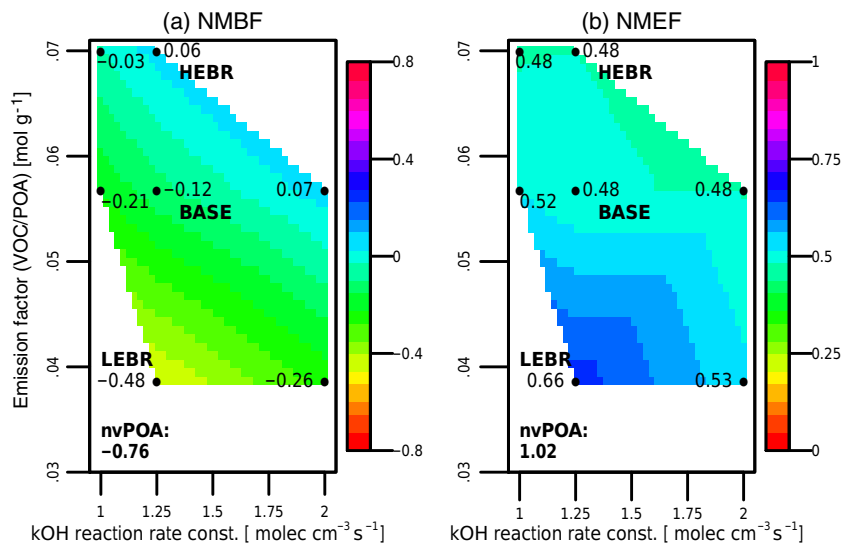

Figure 6. Evaluation of the effect of uncertain parameters for pcSOA formation, emission factor, and $\mathrm{OH}$ reaction rate constant for the CAL domain. The normalized mean bias factor (NMBF) and normalized mean error factor (NMEF) symmetrically represent both under- and overprediction.

ern US, for example, relative humidity or acidity may play a larger role for OA formation and deposition. Meanwhile in the wintertime cases, large wood burning area emissions may not result in substantial net OA formation downwind. Although the simulation results shown here take this possible feature into account for wildfire sources, residential and other smaller-scale wood combustion sources are assumed to produce pcSOA consistent with fossil fuel sources. If these sources are significantly overpredicted, then lower pcSOA production rates would yield better agreement at the CONUS 

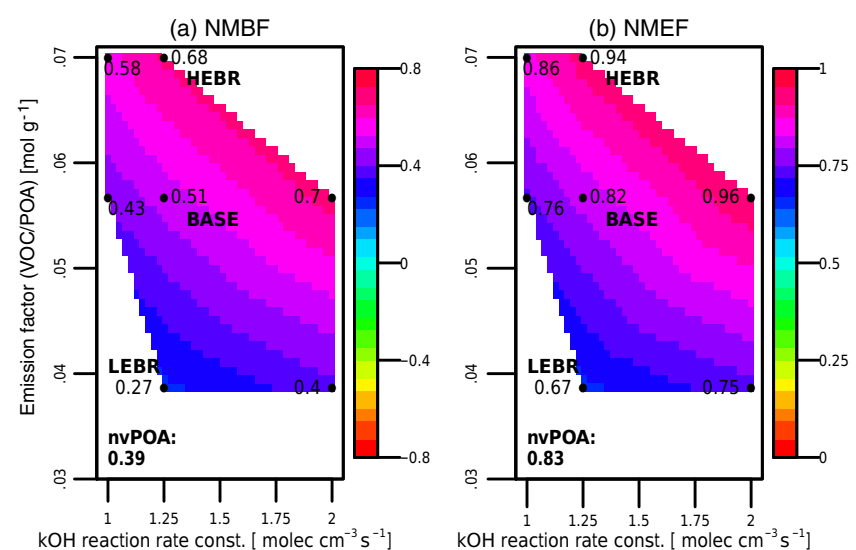

Figure 7. Evaluation of the effect of uncertain parameters for pcSOA formation, emission factor, and $\mathrm{OH}$ reaction rate constant against OC measurements from IMPROVE and CSN networks. Data from January and July only of the CONUS11 simulations were used for this analysis.

scale for the wrong reasons. This possibility will be explored by applying a source-resolved emission inventory to determine how urban SOA formation from vehicles and cooking sources might be better simulated in the future.

\subsection{Evaluation against routine-monitoring data}

We extended the analysis from specific measurement campaigns to a thorough evaluation of a year-long dataset at the continental US scale, CONUS11. For this application, we used daily averaged results from the LEBR model case, which performed best in the January and July CONUS11 scenarios (discussed in Sect. 4.2). Figure 8 summarizes the model performance across both the IMPROVE and CSN networks for the entire year. The MB across all CSN modelobservation pairs decreased substantially from the nvPOA (0.88) to the LEBR (0.39) case, while the MB at IMPROVE sites stayed roughly the same. The aggregate improvement across all sites resulted in about a $50 \%$ reduction in $\mathrm{MB}$, a $12 \%$ reduction in mean error, and very little change to the correlation coefficient. As shown in Fig. 8c, error decreases occurred at a majority of sites, with large error decreases at some sites (up to and exceeding $3 \mu \mathrm{gC} \mathrm{m}^{-3}$ ). A minority of sites showed small increases in error, but none showed increases above $0.5 \mu \mathrm{gC} \mathrm{m}^{-3}$. Segregating the data regionally (Fig. 8d) indicated similar changes to the model OC distribution across the US. The new model yielded slightly less variable $\mathrm{OC}$ values (i.e., shorter whiskers) and only small changes to the median OC predictions. Changes to the explanatory power of the model data were mixed, with some regions indicating better correlations (northeast, southeast, Plains), some worse correlations (Midwest, southwest) and some staying the same (northwest). The consistency between the performance of the nvPOA and LEBR cases for the CONUS11 domain was likely due to the coordination of several confounding factors including spatiotemporal variability, uncertainty in emissions and reactivity, and meteorological errors (e.g., wet deposition, boundary layer dynamics). The evaluations presented in Sect. 4.1 demonstrated the extensive influence of temporal averaging: at many sites throughout the CONUS domain, the nvPOA case likely overestimated OC concentrations at night and underestimated them during the day, and these compensating errors averaged out. This stresses the critical need to evaluate models like CMAQ at multiple spatial and temporal scales where data are available.

Figure 9 illustrates the role of seasonal variability. The nvPOA case overpredicted daily averaged OC concentrations in the winter months and underpredicted them in the summer months with correlation coefficients in the range of 0.30.64 . This bias trend is a well-documented feature of models that employ the nvPOA in general (Shrivastava et al., 2008). The LEBR case reduced almost all of the bias in October-December 2011 and some of the bias in January and February, possibly a result of the more accurate temperature dependence in the semivolatile POA model. POA plays a larger role in the winter months than in the summer because of favorable temperature-dependent partitioning. However, without the pcSOA species, the LEBR case would likely have slightly underpredicted the observations in the winter time (see Figs. S5-S7). Meanwhile, performance during the summer months improved slightly for the LEBR case, with significant reduction in bias for July. The transition season months showed smaller bias reductions, with 0.22 , $0.14,0.12$, and $0.14 \mu \mathrm{g} \mathrm{m}^{-3}$ bias reductions for March, April, September, and October, respectively. During these months, the opposing changes induced by POA volatilization and pcSOA formation had highly variable impacts across the US, with dependence on temperature, boundary layer height, and oxidant loadings. The correlation coefficient did not change appreciably from the nvPOA case to the LEBR case, in contrast to the dramatic changes in correlation seen when comparing against California hourly data. A regional evaluation of the NMBF and NMEF metrics broken down by season illustrates that performance in almost every region of the US improved throughout the year from the nvPOA to the LEBR case (Fig. 10). The nvPOA case had the worst-performing predictions during summer, and the LEBR updates moved all but the northeast region into the statistical area defined as acceptable by Yu et al. (2006). Performance during the summer improved for all regions and improved substantially for the northwest. The NMBF was reduced for all regions in the fall scenarios although the NMEF changed only slightly. The only degraded performance occurred in the northwest in spring, where the NMBF increased by about a factor of 2 and the NMEF by a factor of 3 . This is likely driven by errors in the emissions and aging of POA from fire events and should be investigated in the future as more is learned about the identity and fate of the compounds emitted by this group of sources. 


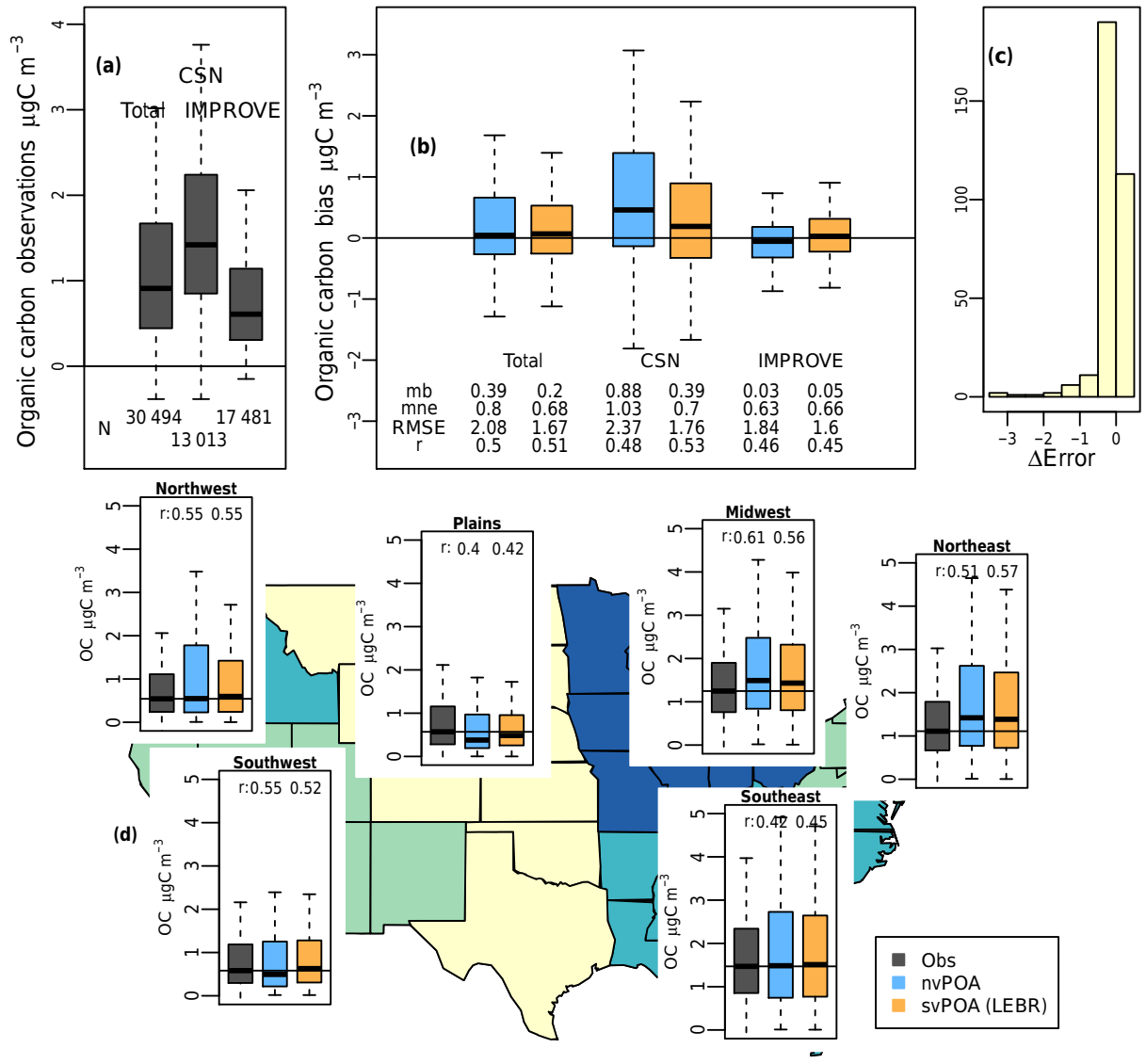

Figure 8. Continent-wide organic carbon (OC) evaluation of the nvPOA case and the best-performing sensitivity case (LEBR) against routine-monitoring data from IMPROVE and CSN sites for an annual simulation during 2011. (a) Distribution of OC observations from both networks individually and combined. (b) Distributions of OC bias for each network and combined. (c) Histogram of error changes from the nvPOA to the svPOA (LEBR) case at specific stations aggregated throughout the year. (d) Regional distribution of OC observations and predictions throughout the annual simulation.

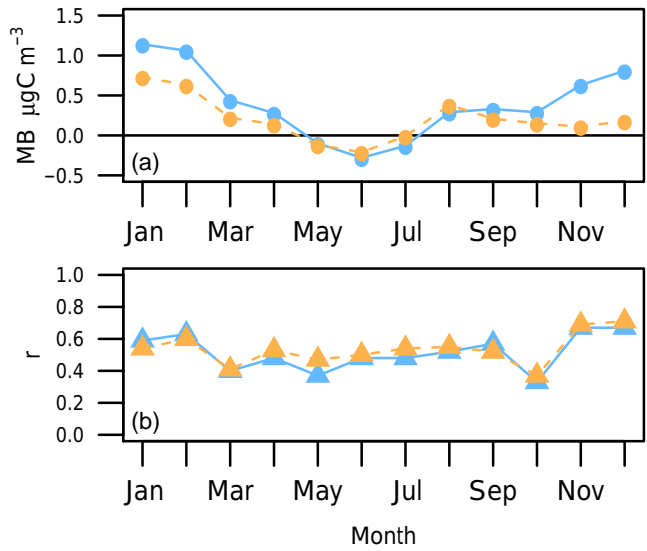

Figure 9. Monthly model performance for the nvPOA (blue) and LEBR (orange) cases throughout the 2011 simulation. The top panel indicates the mean $\mathrm{OC}$ bias, while the bottom panel indicates the correlation coefficient of each model run with the CSN and IMPROVE observations.

\subsection{OA spatiotemporal composition in CMAQ}

The total OA surface concentrations predicted by the model vary considerably from winter to summer for many regions of the nation (top row of Fig. 11). In the winter, urban locations emerge as the sources mainly driving the regional OA distribution, whereas, in the summer, these urban centers compete with heavily forested regions of the country like the southeast and the Sierra Nevadas. Although the abundance of biogenic OA observed for 6 weeks at the Centreville site (Xu et al., 2015) is qualitatively reproduced by the model, significant uncertainties exist in our knowledge of the air-surface exchange of important biogenic precursors, their SOA yields, and the partitioning properties of their oxidation products. The annually averaged contribution of POA (unreacted primary compounds in the particulate phase) predicted by the model is in the range of 5-10\%, increasing to $30 \%$ in some cities, especially at high elevations with colder temperatures, which is in the same range as the observations (Jimenez et al., 2009). These maxima are driven by winter- 
time episodes when the atmospheric lifetime of POA against evaporation and gas-phase oxidation increases substantially. The LEBR model predicted that in the summer there is little contribution of these fresh emissions to particulate loadings as most of the mass was predicted to be oxidized quickly in the gas phase. CMAQv5.2 with the LEBR configuration should be evaluated against AMS-inferred HOA concentrations at cities characterized by higher wintertime POA fractions (e.g., Xu et al., 2015).

The pcSOA concentrations are driven both by variability in primary pcVOC emissions and by efficient photochemical oxidation, as illustrated by Fig. 11 (third row). The summertime concentration field was similar to that of the total OA concentrations and was relatively dispersed in the eastern US like other regional secondary pollutants (e.g., ozone, particulate nitrate). Interestingly, the wintertime concentration field in the east was more dispersed than in the summer because of the longer lifetime of pcVOC against oxidation to pcSOG. The increased role of residential wood combustion emissions led to elevated pcSOA concentrations in the northeast US compared to those in the summer. The pcVOC emission sources in the western US were visually evident from the pcSOA concentration field in both the summer and winter simulations, mostly due to relatively less population density in western states compared to the east. An interesting dynamic associated with pcSOA appeared in California. In the summer, enhanced photochemistry caused high pcSOA concentrations in southern California $\left(4 \mu \mathrm{gC} \mathrm{m}^{-3}\right)$. Meanwhile, concentrations were elevated but not as much in the San Joaquin Valley. The relationship was flipped in the wintertime where concentrations were low in southern California and much higher in the valley. The wintertime San Joaquin Valley enhancement was likely due to lower boundary layer heights enhancing the oxidative capacity of the airshed and increasing the formation rate of pcSOA. Future work will investigate episodes like this to determine if more can be learned about how the contributions of various SOA pathways vary seasonally. The percent change in POA concentrations from the nvPOA to the LEBR cases was highest during the summer and far from urban sources, as expected. For this study, the POA boundary conditions were renamed SOA and highly affect the percent change in POA close to the model boundaries. In the summer time, the change in POA concentrations in the domain interior varied from -100 to $-70 \%$ change in California. The winter simulations showed more variability ( -100 to $-55 \%$ change), indicating that even when treating POA as semivolatile, it is still an important component of urban and suburban particulate loadings and important to consider in exposure assessments.

\subsection{Multiyear organic carbon trends}

For many policy and environmental applications, it is important for the model to capture trends in ambient concentrations in response to emissions changes. In order to probe
CMAQv5.2 sensitivity to changes in real-world emissions from 2002 to 2011, we applied the model (both the nvPOA and LEBR cases) to the continental US domain during January and July 2002 (CONUSO2) and compared the modeled OC predictions to available CSN and IMPROVE observations (Fig. 12). The OC trend for IMPROVE sites between January 2002 and January 2011 were relatively flat and the model reproduced the behavior for both cases. The January CSN site trends were more complex. While the observations indicated a decrease of $0.92 \mu \mathrm{gC} \mathrm{m}^{-3} \mathrm{yr}^{-1}$, both the nvPOA and LEBR model cases predicted increases of 0.87 and $0.65 \mu \mathrm{gC} \mathrm{m}^{-3} \mathrm{yr}^{-1}$, respectively. Because this deviation occurs in the context of wintertime scenarios, uncertainties from emissions or misrepresented boundary layer dynamics likely play a more important role. With more realistic emissions from this source, both CMAQv5.2 model configurations would predict greater $\mathrm{OC}$, potentially overpredicting the observations by a similar magnitude as the 2011 datasets.

Both CSN and IMPROVE sites during July show a similar trend, although it is exacerbated for CSN sites. Here, the observations indicate dramatic OC decreases $\left(-5.72 \% \mathrm{yr}^{-1}\right)$, while the nvPOA and LEBR models predict increases by $4.28 \%$ and $3.65 \% \mathrm{yr}^{-1}$, respectively. Clearly the model is missing an important source or pathway for OC formation in the 2002 simulation. The 2011 predictions overlap reasonably with the observations, so this pathway either diminishes substantially when moving to the 2011 scenario or there is a coincident offset by other pathways that may be overestimated by the model in 2011. The 2002 CSN observations are potentially biased by the application of the National Institute for Occupational Safety and Health (NIOSH) method; the IMPROVE (2002 and 2011) and the CSN 2011 observations were gathered using the IMPROVE method, which is consistent with the characterization of the POA emission factors used to build the emission inventory. Because the differences between the NIOSH and IMPROVE methods affects the observed ratio of OC to elemental carbon (EC), the potential magnitude of $\mathrm{OC}$ bias can be estimated by inspecting the bias in EC. For the CSN 2002 dataset, the MB for EC is $0.2 \mu \mathrm{g} \mathrm{m}^{-3}$, indicating that most of the underprediction at CSN sites in summer 2002 is not related to discrepancies between measurement methods.

One possible formation pathway of particle-phase OC mass that could have been higher in 2002 involves perturbations of aerosol liquid water concentrations. Carlton and Turpin (2013), Pye et al. (2013), and Pye et al. (2017) argued that higher aerosol water concentrations, possibly resulting from increased sulfate concentrations in the past, could have enhanced the partitioning of semivolatile organic compounds, depending on their solubility, or they could have enhanced reactive uptake rates of VOC oxidation products. This is consistent with $\mathrm{Xu}$ et al. (2017), who showed that $88 \%$ of OA were water soluble at the Centreville site during SOAS and that only $25-40 \%$ of the total water-soluble organic compounds were in the particle phase throughout the 

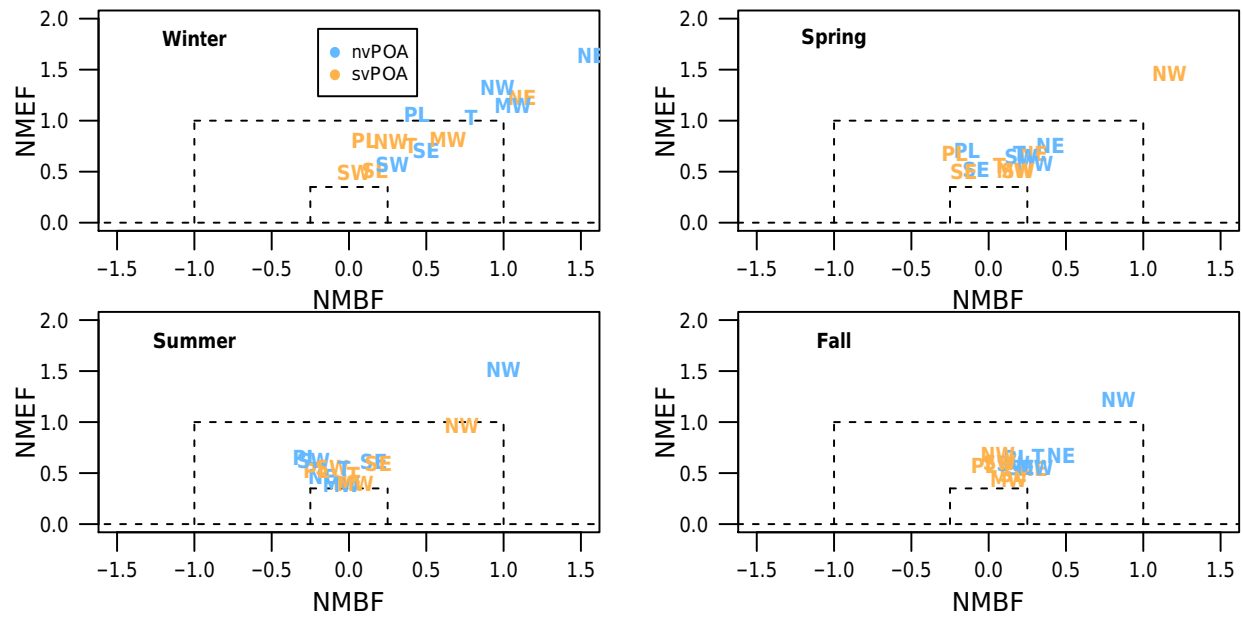

Figure 10. Regional and seasonal model performance at routine-monitoring stations for the CONUS11 simulation as a function of the normalized mean bias factor (NMBF) and normalized mean error factor (NMEF) for OC predictions. Plotted regions include the northeast (NE), Midwest (MW), southeast (SE), Plains (PL), northwest (NW), southwest (SW), and total (T) and are defined as visualized in Fig. 8.

day. Figure 13 indicates the trend toward higher OC biases as sulfate increases. This trend occurred despite the fact that sulfate and elemental carbon aerosol predictions did not underestimate observations as did OC predictions. CMAQv5.2 includes the aerosol-water dependent pathway of isoprene OA formation via IEPOX (isoprene-epoxydiol) processing. A similar interaction among products of anthropogenic VOC oxidation may be responsible for the discrepancy in the urban-influenced CSN sites. Another potential OC pathway, organic nitrate formation, could have played a larger role in 2002 and diminished over the last decade due to decreased $\mathrm{NO}_{x}$ emissions (e.g., Pye et al., 2015). Those authors showed that a $25 \%$ reduction in $\mathrm{NO}_{x}$ led to a $25 \%$ reduction in organic nitrate SOA. Since 2002, $\mathrm{NO}_{x}$ concentrations in the US have decreased due to the implementation of the $\mathrm{NO}_{x}$ Budget Trading Program (or $\mathrm{NO}_{x}$ SIP Call and the Clean Air Interstate Rule). For the combined 2002 and 2011 CSN dataset, the $\mathrm{OC}$ underprediction improved from almost $-5 \mu \mathrm{gC} \mathrm{m}{ }^{-3}$ at $50-60$ pbbV $\mathrm{NO}_{x}$ to unbiased at 10 ppbv $\mathrm{NO}_{x}$ and less. Although these relationships are not mechanistic proof of a relationship between $\mathrm{OC}$ aerosol formation and $\mathrm{SO}_{2}$ or $\mathrm{NO}_{x}$ emissions, they do encourage further scrutiny of potential co-benefits that reducing the latter two pollutants has on OA burden and thus public health. Finally, it is possible that the ratio of POA to intermediate and high-volatility unspeciated organic combustion emissions changed from 2002 to 2011 as new emissions controls and fuel formulations were adopted (May et al., 2014). Thus, the analysis presented here may speak to the robustness of using the pcSOA approach for regulatory applications. Fully quantifying the impacts of the pcSOA assumption would require comparing to simulations that include both speciated, source-specific, and year-specific NMOG estimates in the emissions input generation process and accurate speciated SOA yields in the CTM.

\section{Conclusions}

We have shown that CMAQv5.2 with a semivolatile representation of POA compounds and an introduction of the lumped pcSOA model species predicts organic aerosol concentrations acceptably against high-time-resolution field campaign data and daily averaged routine-monitoring network products. In almost all cases, the model improves diurnal and seasonal trends compared to the model with nonvolatile POA - a consequence of better representation of both temperature sensitivity and photochemical oxidation dependence. Because the BASE model is able to achieve similar performance to other more-complicated approaches to OA formation, we advise the OA fate and transport modeling community to consider adding complexity only when there is enough experimental data to provide an associated reduction in uncertainty.

The discrepancy between the optimal parameters inferred from the CAL and CONUS11 simulations highlights the importance of not overstating the meaningfulness of pcSOA or the value of the optimal parameters presented here. Because these parameters are fit to available observations, they lose some explanatory power as one extrapolates to other domains or time periods. However, the essential features of modeled pcSOA formation, the oxidation of a VOC precursor followed by condensation to the particle phase, broadly represent the transformations of most of the likely pathways to OA formation needed by the model. This approach parallels the more-detailed, but still very uncertain, approaches used in similar CTMs simulating OA from primary sources (Fast et al., 2014; Koo et al., 2014) while maintaining consistency with existing regulatory inventories developed over decades. For these reasons, we feel confident that CMAQv5.2 with semivolatile POA and pcSOA is a substantial step toward a 

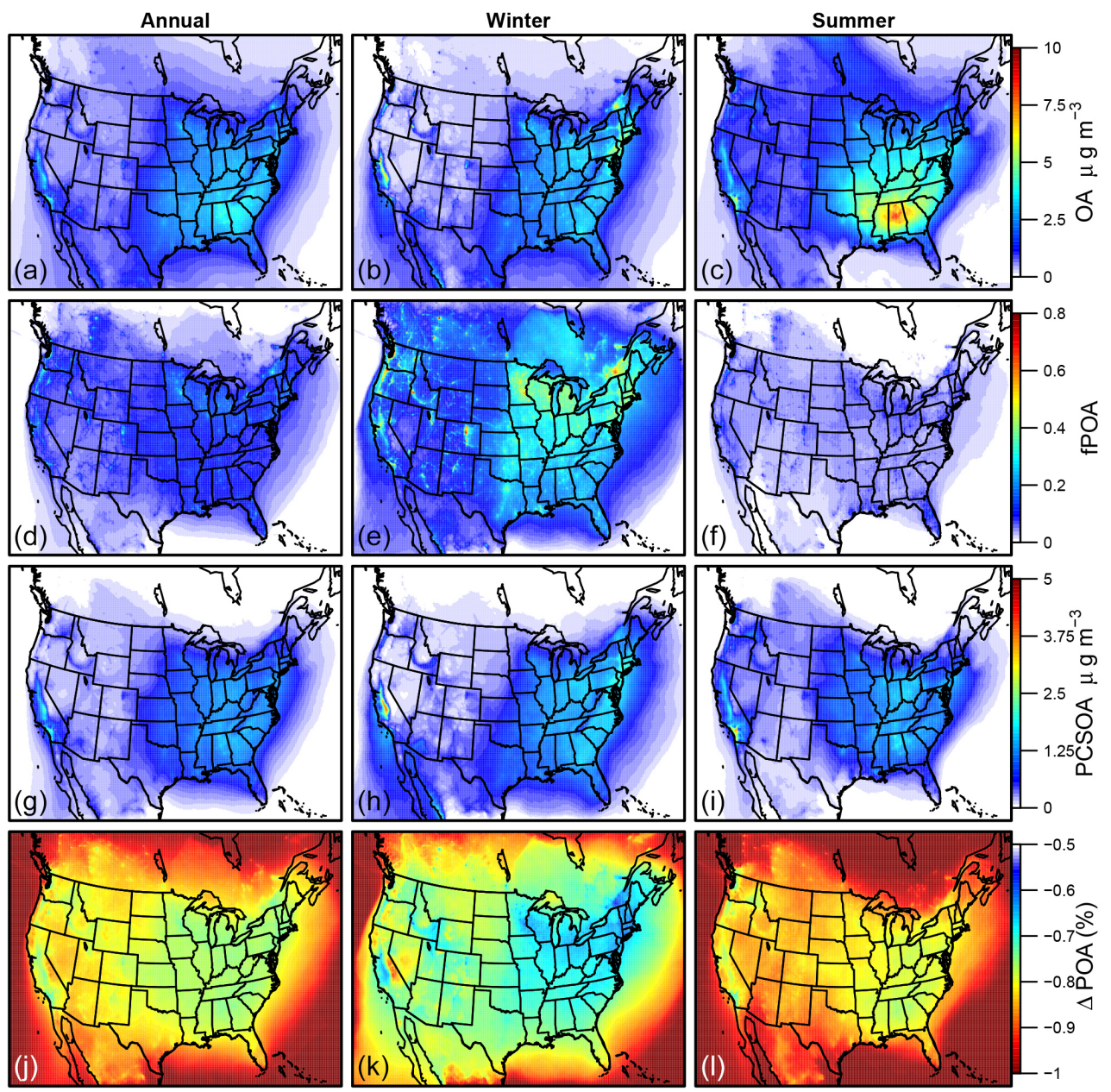

Figure 11. Spatial distribution of products form the LEBR CONUS11 simulation. Products include the OA concentration (row 1), fraction of POA (row 2), pcSOA concentration (row 3), and change in model-predicted POA from the nonvolatile POA model to the semivolatile POA model (row 4). Maps illustrate the median of all annual surface data (a, d, $\mathbf{g}$, j), winter months (December, January, February; $\mathbf{b}, \mathbf{e}, \mathbf{h}, \mathbf{k}$ ), and summer months (June, July, August; $\mathbf{c}, \mathbf{f}, \mathbf{i}, \mathbf{l}$ ).
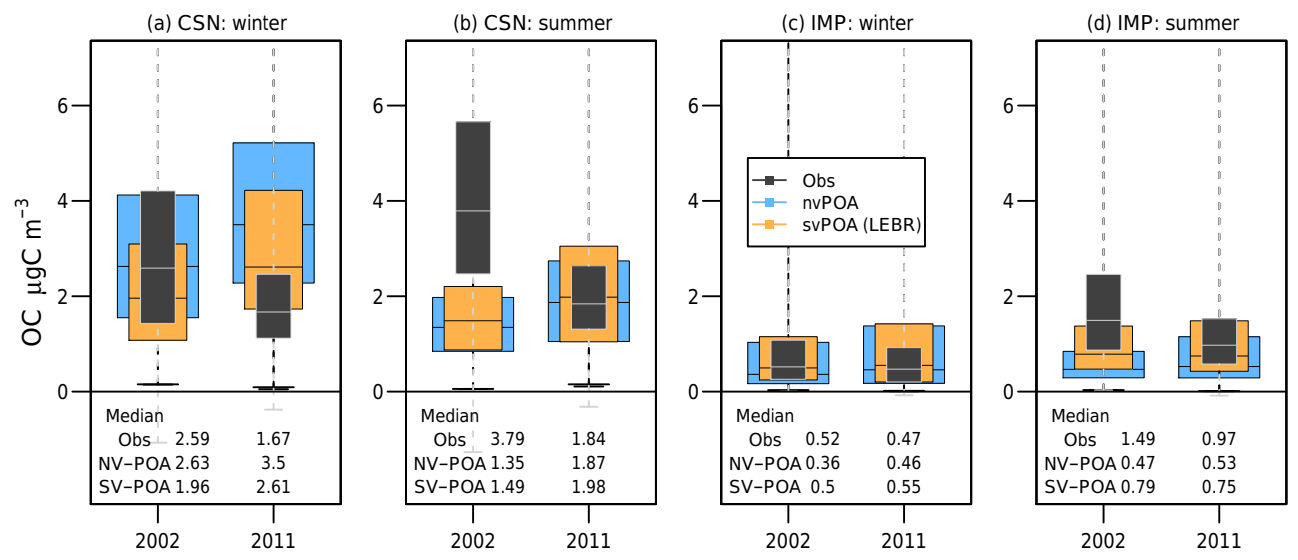

Figure 12. Organic carbon (OC) distributions for routine-monitoring stations and model predictions at the same locations and times. The meaning of the boxes and whiskers is explained in Fig. 5. 


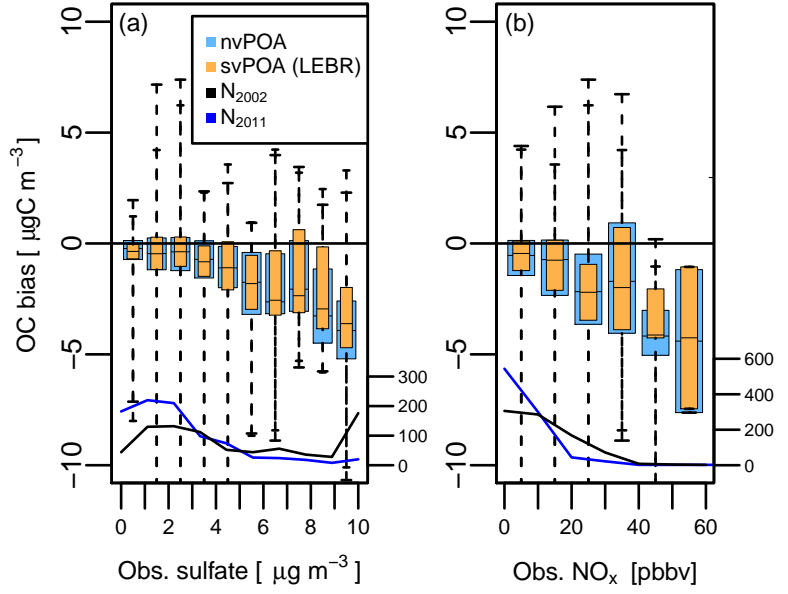

Figure 13. Organic carbon bias for CSN summer time data during 2002 and 2011 (combined) as a function of observed sulfate concentrations (a) and observed $\mathrm{NO}_{x}$ concentrations (b). The meaning of boxes and whiskers is explained in Fig. 5. Blue (2011) and black (2002) solid lines quantify the number of data points for each year as functions of the observed pollutants.

more accurate representation of OA formation, even though future work will focus on replacing the pcSOA species with specific mechanisms constrained by direct measurements.

Based on the limitations discussed in this work, we recommend the chemical transport modeling community address the following concerns:

- The entire volatility spectrum of primary organic emissions, including IVOCs, should be incorporated directly into emission inventories and applied to model input as a function of relevant parameters like combustion technology and fuel type.

- Because of their unique properties and variable OA formation potential, organic compound emissions from biomass burning sources will likely need to be treated distinctly from fossil fuel combustion sources in CTMs. For wildfires the net added mass due to SOA formation, relative to the initial POA mass, is 1-2 orders of magnitude lower than for urban sources (Cubison et al., 2011).

- Aerosol-water interactions are an important complexity to incorporate consistently in CTMs. These interactions not only impact OA loading (Pye et al., 2017) but have important implications for deposition rates, diurnal profiles, multiyear trends, and model response to the simulated control strategy.

- Organic nitrates were detected at multiple sites during the CalNex, CARES, and SOAS campaigns. A consistent treatment of these compounds and the effect nitrate group addition has on volatility and solubility is needed.

- In general, greater efforts are needed to improve the conceptual link between the gas- and aerosol-phase chemical components in CTMs. An example of this approach is described for isoprene epoxide degradation by Pye et al. (2013) and monoterpene nitrate formation by Pye et al. (2015).

We further identify the following potential measurement efforts as useful for addressing critical gaps in our current understanding of OA formation:

- Winter-time ambient observations of urban OA in multiple cities with varying meteorology. Observations are needed at high time resolution (at or greater than $1 \mathrm{~h}$ ) in order to discern important sensitivities to photooxidation, temperature, and atmospheric water content. Important properties to constrain are the POA fraction, volatility/solubility, and aging timescales.

- Detailed transport model comparisons to existing and upcoming measurements of ambient biomass burning plumes including characterization of potential downwind SOA enhancement as well as aging effects on volatility/solubility (e.g., Forrister et al., 2015).

- Updated quantitative estimates of SOA yields as a function of volatility/solubility that take into account losses of low-volatility vapors to chamber walls.

We conclude that the important OA mass formation processes are most likely regional in scale and that OA concentrations tend to be regionally distributed in the US, especially in summer. However, we also emphasize that, despite the diminished contribution direct POA emissions have in the model predictions as a result of evaporation, they are still a critical component to consider, especially for exposure assessments near primary sources, urban centers, and in the winter. Moreover, the evaporated POA compounds likely react in the vapor phase and may contribute to particle concentrations again quickly or they may contribute to the formation of oligomer species, about which little is known with certainty.

The multiyear trends in Figs. 12 and 13 highlight the difficulty in integrating OA formation and properties into models to be used for regulatory applications. If interactions with regulated pollutants (e.g., $\mathrm{SO}_{2}, \mathrm{NO}_{x}$ ) are important contributors to OA formation, then the applicability of a model configuration to a specific scenario may change over time as the concentration of those pollutants decreases. Pathways that used to be important may become less so and vice versa, thus demonstrating the benefit of evaluating the model for a wide array of atmospheric conditions. Characterizing model results with this dynamic view helps improve the robustness of the model over time and guide future policy decisions and research. 
Code and data availability. The CMAQv5.2 code for both the semivolatile and nonvolatile POA options is available via the GitHub repository (https://github.com/usepa/cmaq). Data included in figures are available upon request to the contact author. CalNex measurement data are available through the Earth System Research Laboratory data portal (https://www.esrl.noaa.gov/csd/groups/csd7/ measurements/2010calnex/, CalNex measurement data, 2012), CARES data are available through the DOE Atmospheric Radiation Measurement program portal (http://www.archive.arm.gov/ discovery/\#v/results/s/fiop::aaf2009carbonaerosol, CARES measurement data, 2010), and SOAS data are available through the Southeast Atmosphere Study website (https://esrl.noaa.gov/csd/ groups/csd7/measurements/2013senex/, SOAS measurement data, 2014).

\section{The Supplement related to this article is available online at https://doi.org/10.5194/acp-17-11107-2017- supplement.}

Competing interests. The authors declare that they have no conflict of interest.

Acknowledgements. The US EPA, through its Office of Research and Development, supported the research described here. The research has been subjected to agency administrative review and approved for publication but may not necessarily reflect official agency policy. The authors gratefully acknowledge Heather Simon (Office of Air Quality Planning and Standards) and Brian Eder (National Exposure Research Laboratory) from the US EPA for their helpful comments during the agency review process. Jose L. Jimenez was supported by EPA STAR 83587701-0 and National Science Foundation (NSF) AGS-1360834. Shang Liu and Lynn M. Russell were supported by the California Air Resources Board (contract 09-328). Funding for data collection during the CARES campaign was provided by the Atmospheric Radiation Measurement (ARM) Program sponsored by the US Department of Energy (DOE), Office of Biological and Environmental Research (OBER). Rahul A. Zaveri was supported by the US DOE's Atmospheric Systems Research (ASR) program under contract DE-AC06-76RLO 1830 at the Pacific Northwest National Laboratory. Qi Zhang and Ari Setyan were supported by DOE ASR DE-FG02-11ER65293. Lu Xu and Nga L. Ng acknowledge NSF grant 1242258 and US EPA STAR grant RD-83540301.

Edited by: Manabu Shiraiwa

Reviewed by: two anonymous referees

\section{References}

Ahmadov, R., McKeen, S. A., Robinson, A. L., Bahreini, R., Middlebrook, A. M., de Gouw, J. A., Meagher, J., Hsie, E. Y., Edgerton, E., Shaw, S., and Trainer, M.: A volatility basis set model for summertime secondary organic aerosols over the eastern United States in 2006, J. Geophys. Res.-Atmos., 117, D06301, https://doi.org/10.1029/2011JD016831, 2012.
Aiken, A. C., Decarlo, P. F., Kroll, J. H., Worsnop, D. R., Huffman, J. A., Docherty, K. S., Ulbrich, I. M., Mohr, C., Kimmel, J. R., and Sueper, D.: O/C and OM/OC ratios of primary, secondary, and ambient organic aerosols with high-resolution timeof-flight aerosol mass spectrometry, Environ. Sci. Technol., 42, 4478-4485, 2008.

Appel, K. W., Napelenok, S. L., Foley, K. M., Pye, H. O. T., Hogrefe, C., Luecken, D. J., Bash, J. O., Roselle, S. J., Pleim, J. E., Foroutan, H., Hutzell, W. T., Pouliot, G. A., Sarwar, G., Fahey, K. M., Gantt, B., Gilliam, R. C., Heath, N. K., Kang, D., Mathur, R., Schwede, D. B., Spero, T. L., Wong, D. C., and Young, J. O.: Description and evaluation of the Community Multiscale Air Quality (CMAQ) modeling system version 5.1, Geosci. Model Dev., 10, 1703-1732, https://doi.org/10.5194/gmd-10-1703-2017, 2017.

Bahreini, R., Middlebrook, A., Gouw, J. d., Warneke, C., Trainer, M., Brock, C., Stark, H., Brown, S., Dube, W., and Gilman, J.: Gasoline emissions dominate over diesel in formation of secondary organic aerosol mass, Geophys. Res. Lett., 39, L06805, https://doi.org/10.1029/2011GL050718, 2012.

Baker, K. R., Misenis, C., Obland, M. D., Ferrare, R. A., Scarino, A. J., and Kelly, J. T.: Evaluation of surface and upper air fine scale WRF meteorological modeling of the May and June 2010 CalNex period in California, Atmos. Environ., 80, 299-309, https://doi.org/10.1016/j.atmosenv.2013.08.006, 2013.

Baker, K. R., Carlton, A. G., Kleindienst, T. E., Offenberg, J. H., Beaver, M. R., Gentner, D. R., Goldstein, A. H., Hayes, P. L., Jimenez, J. L., Gilman, J. B., de Gouw, J. A., Woody, M. C., Pye, H. O. T., Kelly, J. T., Lewandowski, M., Jaoui, M., Stevens, P. S., Brune, W. H., Lin, Y.-H., Rubitschun, C. L., and Surratt, J. D.: Gas and aerosol carbon in California: comparison of measurements and model predictions in Pasadena and Bakersfield, Atmos. Chem. Phys., 15, 5243-5258, https://doi.org/10.5194/acp15-5243-2015, 2015.

Bash, J. O., Cooter, E. J., Dennis, R. L., Walker, J. T., and Pleim, J. E.: Evaluation of a regional air-quality model with bidirectional $\mathrm{NH}_{3}$ exchange coupled to an agroecosystem model, Biogeosciences, 10, 1635-1645, https://doi.org/10.5194/bg-101635-2013, 2013.

Bergström, R., Denier van der Gon, H. A. C., Prévôt, A. S. H., Yttri, K. E., and Simpson, D.: Modelling of organic aerosols over Europe (2002-2007) using a volatility basis set (VBS) framework: application of different assumptions regarding the formation of secondary organic aerosol, Atmos. Chem. Phys., 12, 8499-8527, https://doi.org/10.5194/acp-12-8499-2012, 2012.

Borbon, A., Gilman, J. B., Kuster, W. C., Grand, N., Chevaillier, S., Colomb, A., Dolgorouky, C., Gros, V., Lopez, M., Sarda-Esteve, R., Holloway, J., Stutz, J., Petetin, H., McKeen, S., Beekmann, M., Warneke, C., Parrish, D. D., and de Gouw, J. A.: Emission ratios of anthropogenic volatile organic compounds in northern mid-latitude megacities: Observations versus emission inventories in Los Angeles and Paris, J. Geophys. Res.-Atmos., 118, 2041-2057, https://doi.org/10.1002/jgrd.50059, 2013.

Boyd, C. M., Sanchez, J., Xu, L., Eugene, A. J., Nah, T., Tuet, W. Y., Guzman, M. I., and Ng, N. L.: Secondary organic aerosol formation from the $\beta$-pinene $+\mathrm{NO}_{3}$ system: effect of humidity and peroxy radical fate, Atmos. Chem. Phys., 15, 7497-7522, https://doi.org/10.5194/acp-15-7497-2015, 2015. 
Budisulistiorini, S. H., Li, X., Bairai, S. T., Renfro, J., Liu, Y., Liu, Y. J., McKinney, K. A., Martin, S. T., McNeill, V. F., Pye, H. O. T., Nenes, A., Neff, M. E., Stone, E. A., Mueller, S., Knote, C., Shaw, S. L., Zhang, Z., Gold, A., and Surratt, J. D.: Examining the effects of anthropogenic emissions on isoprenederived secondary organic aerosol formation during the 2013 Southern Oxidant and Aerosol Study (SOAS) at the Look Rock, Tennessee ground site, Atmos. Chem. Phys., 15, 8871-8888, https://doi.org/10.5194/acp-15-8871-2015, 2015.

CalNex measurement data: NOAA Earth System Research Laboratory, CalNex 2010, available at: https://www.esrl.noaa.gov/ csd/groups/csd7/measurements/2010calnex/ (last access: $18 \mathrm{Au}-$ gust 2016), 2012.

Canagaratna, M. R., Jimenez, J. L., Kroll, J. H., Chen, Q., Kessler, S. H., Massoli, P., Hildebrandt Ruiz, L., Fortner, E., Williams, L. R., Wilson, K. R., Surratt, J. D., Donahue, N. M., Jayne, J. T., and Worsnop, D. R.: Elemental ratio measurements of organic compounds using aerosol mass spectrometry: characterization, improved calibration, and implications, Atmos. Chem. Phys., 15, 253-272, https://doi.org/10.5194/acp-15-253-2015, 2015.

Cappa, C. D. and Wilson, K. R.: Multi-generation gas-phase oxidation, equilibrium partitioning, and the formation and evolution of secondary organic aerosol, Atmos. Chem. Phys., 12, 9505-9528, https://doi.org/10.5194/acp-12-9505-2012, 2012.

Cappa, C. D., Jathar, S. H., Kleeman, M. J., Docherty, K. S., Jimenez, J. L., Seinfeld, J. H., and Wexler, A. S.: Simulating secondary organic aerosol in a regional air quality model using the statistical oxidation model - Part 2: Assessing the influence of vapor wall losses, Atmos. Chem. Phys., 16, 3041-3059, https://doi.org/10.5194/acp-16-3041-2016, 2016.

CARES measurement data: DOE Atmospheric Radiation Measurement Program, Carbonaceous Aerosol and Radiative Effects Study, available at: http://www.archive.arm.gov/discovery/ \#v/results/s/fiop::aaf2009carbonaerosol (last access: $18 \mathrm{Au}-$ gust 2016), 2010.

Carlton, A. G. and Baker, K. R.: Photochemical modeling of the Ozark isoprene volcano: MEGAN, BEIS, and their impacts on air quality predictions, Environ. Sci. Technol., 45, 4438-4445, https://doi.org/10.1021/es200050x, 2011.

Carlton, A. G. and Turpin, B. J.: Particle partitioning potential of organic compounds is highest in the Eastern US and driven by anthropogenic water, Atmos. Chem. Phys., 13, 10203-10214, https://doi.org/10.5194/acp-13-10203-2013, 2013.

Carlton, A. G., Bhave, P. V., Napelenok, S. L., Edney, E. O., Sarwar, G., Pinder, R. W., Pouliot, G. A., and Houyoux, M.: Model Representation of Secondary Organic Aerosol in CMAQv4.7, Environ. Sci. Technol., 44, 8553-8560, https://doi.org/10.1021/es100636q, 2010.

Carlton, A. M., de Gouw, J., Jimenez, J. L., Ambrose, J. L., Brown, S., Baker, K. R., Brock, C. A., Cohen, R. C., Edgerton, S., Farkas, C., Farmer, D. K., Goldstein, A. H., Gratz, L., Guenther, A., Hunt, S., Jaeglé, L., Jaffe, D. A., Mak, J., McClure, C., Nenes, A., Nguyen, T. K. V., Pierce, J. R., Selin, N. E., Shah, V., Shaw, S., Shepson, P. B., Song, S., Stutz, J., Surratt, J. D., Turpin, B. J., Warneke, C., Washenfelder, R. A., Wennberg, P. O., and Zhou, X.: The Southeast Atmosphere Studies: coordinated investigation of fundamental atmospheric chemistry questions, B. Am. Meteorol. Soc., submitted, 2016.
Chan, A. W. H., Isaacman, G., Wilson, K. R., Worton, D. R., Ruehl, C. R., Nah, T., Gentner, D. R., Dallmann, T. R., Kirchstetter, T. W., Harley, R. A., Gilman, J. B., Kuster, W. C., de Gouw, J. A., Offenberg, J. H., Kleindienst, T. E., Lin, Y. H., Rubitschun, C. L., Surratt, J. D., Hayes, P. L., Jimenez, J. L., and Goldstein, A. H.: Detailed chemical characterization of unresolved complex mixtures in atmospheric organics: Insights into emission sources, atmospheric processing, and secondary organic aerosol formation, J. Geophys. Res.-Atmos., 118, 6783-6796, https://doi.org/10.1002/jgrd.50533, 2013.

Chuang, W. K. and Donahue, N. M.: A two-dimensional volatility basis set - Part 3: Prognostic modeling and NOx dependence, Atmos. Chem. Phys., 16, 123-134, https://doi.org/10.5194/acp16-123-2016, 2016.

Cubison, M. J., Ortega, A. M., Hayes, P. L., Farmer, D. K., Day, D., Lechner, M. J., Brune, W. H., Apel, E., Diskin, G. S., Fisher, J. A., Fuelberg, H. E., Hecobian, A., Knapp, D. J., Mikoviny, T., Riemer, D., Sachse, G. W., Sessions, W., Weber, R. J., Weinheimer, A. J., Wisthaler, A., and Jimenez, J. L.: Effects of aging on organic aerosol from open biomass burning smoke in aircraft and laboratory studies, Atmos. Chem. Phys., 11, 12049-12064, https://doi.org/10.5194/acp-11-12049-2011, 2011.

De Gouw, J. and Jimenez, J. L.: Organic aerosols in the Earth's atmosphere, Environ. Sci. Technol., 43, 7614-7618, https://doi.org/10.1021/es9006004, 2009.

Donahue, N. M., Robinson, A. L., Stanier, C. O., and Pandis, S. N.: Coupled Partitioning, Dilution, and Chemical Aging of Semivolatile Organics, Environ. Sci. Technol., 40, 2635-2643, https://doi.org/10.1021/es052297c, 2006.

Donahue, N. M., Robinson, A. L., and Pandis, S. N.: Atmospheric organic particulate matter: From smoke to secondary organic aerosol, Atmos. Environ., 43, 94-106, https://doi.org/10.1016/j.atmosenv.2008.09.055, 2009.

Donahue, N. M., Epstein, S. A., Pandis, S. N., and Robinson, A. L.: A two-dimensional volatility basis set: 1. organic-aerosol mixing thermodynamics, Atmos. Chem. Phys., 11, 3303-3318, https://doi.org/10.5194/acp-11-3303-2011, 2011.

Donahue, N. M., Kroll, J. H., Pandis, S. N., and Robinson, A. L.: A two-dimensional volatility basis set - Part 2: Diagnostics of organic-aerosol evolution, Atmos. Chem. Phys., 12, 615-634, https://doi.org/10.5194/acp-12-615-2012, 2012.

Donahue, N. M., Chuang, W., Epstein, S. A., Kroll, J. H., Worsnop, D. R., Robinson, A. L., Adams, P. J., and Pandis, S. N.: Why do organic aerosols exist? Understanding aerosol lifetimes using the two-dimensional volatility basis set, Environ. Chem., 10, 151157, https://doi.org/10.1071/EN13022, 2013.

Dzepina, K., Volkamer, R. M., Madronich, S., Tulet, P., Ulbrich, I. M., Zhang, Q., Cappa, C. D., Ziemann, P. J., and Jimenez, J. L.: Evaluation of recently-proposed secondary organic aerosol models for a case study in Mexico City, Atmos. Chem. Phys., 9, 5681-5709, https://doi.org/10.5194/acp-9-5681-2009, 2009.

Dzepina, K., Cappa, C. D., Volkamer, R. M., Madronich, S., DeCarlo, P. F., Zaveri, R. A., and Jimenez, J. L.: Modeling the multiday evolution and aging of secondary organic aerosol during MILAGRO 2006, Environ. Sci. Technol., 45, 3496-3503, 2011.

Ensberg, J. J., Hayes, P. L., Jimenez, J. L., Gilman, J. B., Kuster, W. C., de Gouw, J. A., Holloway, J. S., Gordon, T. D., Jathar, S., Robinson, A. L., and Seinfeld, J. H.: Emission factor ratios, SOA mass yields, and the impact of vehicular emis- 
sions on SOA formation, Atmos. Chem. Phys., 14, 2383-2397, https://doi.org/10.5194/acp-14-2383-2014, 2014.

Epstein, S. A., Riipinen, I., and Donahue, N. M.: A semiempirical correlation between enthalpy of vaporization and saturation concentration for organic aerosol, Environ. Sci. Technol., 44, 743748, https://doi.org/10.1021/es902497z, 2010.

Farina, S. C., Adams, P. J., and Pandis, S. N.: Modeling global secondary organic aerosol formation and processing with the volatility basis set: Implications for anthropogenic secondary organic aerosol, J. Geophys. Res., 115, D09202, https://doi.org/10.1029/2009jd013046, 2010.

Fast, J. D., Allan, J., Bahreini, R., Craven, J., Emmons, L., Ferrare, R., Hayes, P. L., Hodzic, A., Holloway, J., Hostetler, C., Jimenez, J. L., Jonsson, H., Liu, S., Liu, Y., Metcalf, A., Middlebrook, A., Nowak, J., Pekour, M., Perring, A., Russell, L., Sedlacek, A., Seinfeld, J., Setyan, A., Shilling, J., Shrivastava, M., Springston, S., Song, C., Subramanian, R., Taylor, J. W., Vinoj, V., Yang, Q., Zaveri, R. A., and Zhang, Q.: Modeling regional aerosol and aerosol precursor variability over California and its sensitivity to emissions and long-range transport during the $2010 \mathrm{CalNex}$ and CARES campaigns, Atmos. Chem. Phys., 14, 10013-10060, https://doi.org/10.5194/acp-14-10013-2014, 2014.

Forrister, H., Liu, J., Scheuer, E., Dibb, J., Ziemba, L., Thornhill, K. L., Anderson, B., Diskin, G., Perring, A. E., and Schwarz, J. P.: Evolution of brown carbon in wildfire plumes, Geophys. Res. Lett., 42, 4623-4630, 2015.

Gentner, D. R., Ford, T. B., Guha, A., Boulanger, K., Brioude, J., Angevine, W. M., de Gouw, J. A., Warneke, C., Gilman, J. B., Ryerson, T. B., Peischl, J., Meinardi, S., Blake, D. R., Atlas, E., Lonneman, W. A., Kleindienst, T. E., Beaver, M. R., Clair, J. M. St., Wennberg, P. O., VandenBoer, T. C., Markovic, M. Z., Murphy, J. G., Harley, R. A., and Goldstein, A. H.: Emissions of organic carbon and methane from petroleum and dairy operations in California's San Joaquin Valley, Atmos. Chem. Phys., 14, 4955-4978, https://doi.org/10.5194/acp-14-4955-2014, 2014.

Grieshop, A. P., Logue, J. M., Donahue, N. M., and Robinson, A. L.: Laboratory investigation of photochemical oxidation of organic aerosol from wood fires 1: measurement and simulation of organic aerosol evolution, Atmos. Chem. Phys., 9, 1263-1277, https://doi.org/10.5194/acp-9-1263-2009, 2009.

Hallquist, M., Wenger, J. C., Baltensperger, U., Rudich, Y., Simpson, D., Claeys, M., Dommen, J., Donahue, N. M., George, C., Goldstein, A. H., Hamilton, J. F., Herrmann, H., Hoffmann, T., Iinuma, Y., Jang, M., Jenkin, M. E., Jimenez, J. L., Kiendler-Scharr, A., Maenhaut, W., McFiggans, G., Mentel, Th. F., Monod, A., Prévôt, A. S. H., Seinfeld, J. H., Surratt, J. D., Szmigielski, R., and Wildt, J.: The formation, properties and impact of secondary organic aerosol: current and emerging issues, Atmos. Chem. Phys., 9, 5155-5236, https://doi.org/10.5194/acp9-5155-2009, 2009.

Hayes, P. L., Ortega, A. M., Cubison, M. J., Froyd, K. D., Zhao, Y., Cliff, S. S., Hu, W. W., Toohey, D. W., Flynn, J. H., Lefer, B. L., Grossberg, N., Alvarez, S., Rappenglück, B., Taylor, J. W., Allan, J. D., Holloway, J. S., Gilman, J. B., Kuster, W. C., de Gouw, J. A., Massoli, P., Zhang, X., Liu, J., Weber, R. J., Corrigan, A. L., Russell, L. M., Isaacman, G., Worton, D. R., Kreisberg, N. M., Goldstein, A. H., Thalman, R., Waxman, E. M., Volkamer, R., Lin, Y. H., Surratt, J. D., Kleindienst, T. E., Offenberg, J. H., Dusanter, S., Griffith, S., Stevens, P. S., Brioude,
J., Angevine, W. M., and Jimenez, J. L.: Organic aerosol composition and sources in Pasadena, California, during the 2010 CalNex campaign, J. Geophys. Res.-Atmos., 118, 9233-9257, https://doi.org/10.1002/jgrd.50530, 2013.

Hayes, P. L., Carlton, A. G., Baker, K. R., Ahmadov, R., Washenfelder, R. A., Alvarez, S., Rappenglück, B., Gilman, J. B., Kuster, W. C., de Gouw, J. A., Zotter, P., Prévôt, A. S. H., Szidat, S., Kleindienst, T. E., Offenberg, J. H., Ma, P. K., and Jimenez, J. L.: Modeling the formation and aging of secondary organic aerosols in Los Angeles during CalNex 2010, Atmos. Chem. Phys., 15, 5773-5801, https://doi.org/10.5194/acp-15-5773-2015, 2015.

Heald, C., Kroll, J., Jimenez, J., Docherty, K., DeCarlo, P., Aiken, A., Chen, Q., Martin, S., Farmer, D., and Artaxo, P.: A simplified description of the evolution of organic aerosol composition in the atmosphere, Geophys. Res. Lett., 37, L08803, https://doi.org/10.1029/2010GL042737, 2010.

Henderson, B. H., Akhtar, F., Pye, H. O. T., Napelenok, S. L., and Hutzell, W. T.: A database and tool for boundary conditions for regional air quality modeling: description and evaluation, Geosci. Model Dev., 7, 339-360, https://doi.org/10.5194/gmd-7339-2014, 2014.

Hersey, S. P., Craven, J. S., Metcalf, A. R., Lin, J., Lathem, T., Suski, K. J., Cahill, J. F., Duong, H. T., Sorooshian, A., Jonsson, H. H., Shiraiwa, M., Zuend, A., Nenes, A., Prather, K. A., Flagan, R. C., and Seinfeld, J. H.: Composition and hygroscopicity of the Los Angeles Aerosol: CalNex, J. Geophys. Res.-Atmos., 118, 30163036, https://doi.org/10.1002/jgrd.50307, 2013.

Hildebrandt, L., Donahue, N. M., and Pandis, S. N.: High formation of secondary organic aerosol from the photooxidation of toluene, Atmos. Chem. Phys., 9, 2973-2986, https://doi.org/10.5194/acp-9-2973-2009, 2009.

Hildebrandt Ruiz, L., Paciga, A. L., Cerully, K. M., Nenes, A., Donahue, N. M., and Pandis, S. N.: Formation and aging of secondary organic aerosol from toluene: changes in chemical composition, volatility, and hygroscopicity, Atmos. Chem. Phys., 15, 83018313, https://doi.org/10.5194/acp-15-8301-2015, 2015.

Hodas, N., Zuend, A., Mui, W., Flagan, R. C., and Seinfeld, J. H.: Influence of particle-phase state on the hygroscopic behavior of mixed organic-inorganic aerosols, Atmos. Chem. Phys., 15, 5027-5045, https://doi.org/10.5194/acp-15-5027-2015, 2015.

Hodzic, A. and Jimenez, J. L.: Modeling anthropogenically controlled secondary organic aerosols in a megacity: a simplified framework for global and climate models, Geosci. Model Dev., 4, 901-917, https://doi.org/10.5194/gmd-4-901-2011, 2011.

Hodzic, A., Jimenez, J. L., Madronich, S., Canagaratna, M. R., DeCarlo, P. F., Kleinman, L., and Fast, J.: Modeling organic aerosols in a megacity: potential contribution of semi-volatile and intermediate volatility primary organic compounds to secondary organic aerosol formation, Atmos. Chem. Phys., 10, 5491-5514, https://doi.org/10.5194/acp-10-5491-2010, 2010.

Hodzic, A., Aumont, B., Knote, C., Lee-Taylor, J., Madronich, S., and Tyndall, G.: Volatility dependence of Henry's law constants of condensable organics: Application to estimate depositional loss of secondary organic aerosols, Geophys. Res. Lett., 41, 4795-4804, https://doi.org/10.1002/2014GL060649, 2014.

Hodzic, A., Madronich, S., Kasibhatla, P. S., Tyndall, G., Aumont, B., Jimenez, J. L., Lee-Taylor, J., and Orlando, J.: Organic photolysis reactions in tropospheric aerosols: effect on secondary or- 
ganic aerosol formation and lifetime, Atmos. Chem. Phys., 15, 9253-9269, https://doi.org/10.5194/acp-15-9253-2015, 2015.

Hu, W. W., Campuzano-Jost, P., Palm, B. B., Day, D. A., Ortega, A. M., Hayes, P. L., Krechmer, J. E., Chen, Q., Kuwata, M., Liu, Y. J., de Sá, S. S., McKinney, K., Martin, S. T., Hu, M., Budisulistiorini, S. H., Riva, M., Surratt, J. D., St. Clair, J. M., Isaacman-Van Wertz, G., Yee, L. D., Goldstein, A. H., Carbone, S., Brito, J., Artaxo, P., de Gouw, J. A., Koss, A., Wisthaler, A., Mikoviny, T., Karl, T., Kaser, L., Jud, W., Hansel, A., Docherty, K. S., Alexander, M. L., Robinson, N. H., Coe, H., Allan, J. D., Canagaratna, M. R., Paulot, F., and Jimenez, J. L.: Characterization of a real-time tracer for isoprene epoxydiols-derived secondary organic aerosol (IEPOX-SOA) from aerosol mass spectrometer measurements, Atmos. Chem. Phys., 15, 11807-11833, https://doi.org/10.5194/acp-15-11807-2015, 2015.

Huffman, J., Docherty, K., Mohr, C., Cubison, M., Ulbrich, I., Ziemann, P., Onasch, T., and Jimenez, J.: Chemicallyresolved volatility measurements of organic aerosol from different sources, Environ. Sci. Technol., 43, 5351-5357, 2009a.

Huffman, J. A., Docherty, K. S., Aiken, A. C., Cubison, M. J., U1brich, I. M., DeCarlo, P. F., Sueper, D., Jayne, J. T., Worsnop, D. R., Ziemann, P. J., and Jimenez, J. L.: Chemically-resolved aerosol volatility measurements from two megacity field studies, Atmos. Chem. Phys., 9, 7161-7182, https://doi.org/10.5194/acp9-7161-2009, 2009b

Isaacman-VanWertz, G., Yee, L. D., Kreisberg, N. M., Wernis, R., Moss, J. A., Hering, S. V., de Sa, S. S., Martin, S. T., Alexander, M. L., Palm, B. B., Hu, W., Campuzano-Jost, P., Day, D. A., Jimenez, J. L., Riva, M., Surratt, J. D., Viegas, J., Manzi, A., Edgerton, E., Baumann, K., Souza, R., Artaxo, P., and Goldstein, A. H.: Ambient Gas-Particle Partitioning of Tracers for Biogenic Oxidation, Environ. Sci. Technol., 50, 9952-9962, https://doi.org/10.1021/acs.est.6b01674, 2016.

Jathar, S. H., Farina, S. C., Robinson, A. L., and Adams, P. J.: The influence of semi-volatile and reactive primary emissions on the abundance and properties of global organic aerosol, Atmos. Chem. Phys., 11, 7727-7746, https://doi.org/10.5194/acp11-7727-2011, 2011.

Jathar, S. H., Gordon, T. D., Hennigan, C. J., Pye, H. O. T., Pouliot, G., Adams, P. J., Donahue, N. M., and Robinson, A. L.: Unspeciated organic emissions from combustion sources and their influence on the secondary organic aerosol budget in the United States, P. Natl. Acad. Sci. USA, 111, 10473-10478, https://doi.org/10.1073/pnas.1323740111, 2014

Jathar, S. H., Cappa, C. D., Wexler, A. S., Seinfeld, J. H., and Kleeman, M. J.: Simulating secondary organic aerosol in a regional air quality model using the statistical oxidation model - Part 1: Assessing the influence of constrained multi-generational ageing, Atmos. Chem. Phys., 16, 2309-2322, https://doi.org/10.5194/acp-16-2309-2016, 2016. a.

Jathar, S. H., Mahmud, A., Barsanti, K. C., Asher, W. E., Pankow, J. F., and Kleeman, M. J.: Water uptake by organic aerosol and its influence on gas/particle partitioning of secondary organic aerosol in the United States, Atmos. Environ., 129, 142-154, https://doi.org/10.1016/j.atmosenv.2016.01.001, 2016 b.

Jathar, S. H., Woody, M., Pye, H. O. T., Baker, K. R., and Robinson, A. L.: Chemical transport model simulations of organic aerosol in southern California: model evaluation and gasoline and diesel source contributions, Atmos. Chem. Phys., 17, 43054318, https://doi.org/10.5194/acp-17-4305-2017, 2017.

Jimenez, J. L., Canagaratna, M. R., Donahue, N. M., Prevot, A. S., Zhang, Q., Kroll, J. H., DeCarlo, P. F., Allan, J. D., Coe, H., Ng, N. L., Aiken, A. C., Docherty, K. S., Ulbrich, I. M., Grieshop, A. P., Robinson, A. L., Duplissy, J., Smith, J. D., Wilson, K. R., Lanz, V. A., Hueglin, C., Sun, Y. L., Tian, J., Laaksonen, A., Raatikainen, T., Rautiainen, J., Vaattovaara, P., Ehn, M., Kulmala, M., Tomlinson, J. M., Collins, D. R., Cubison, M. J., Dunlea, E. J., Huffman, J. A., Onasch, T. B., Alfarra, M. R., Williams, P. I., Bower, K., Kondo, Y., Schneider, J., Drewnick, F., Borrmann, S., Weimer, S., Demerjian, K., Salcedo, D., Cottrell, L., Griffin, R., Takami, A., Miyoshi, T., Hatakeyama, S., Shimono, A., Sun, J. Y., Zhang, Y. M., Dzepina, K., Kimmel, J. R., Sueper, D., Jayne, J. T., Herndon, S. C., Trimborn, A. M., Williams, L. R., Wood, E. C., Middlebrook, A. M., Kolb, C. E., Baltensperger, U., and Worsnop, D. R.: Evolution of organic aerosols in the atmosphere, Science, 326, 1525-1529, https://doi.org/10.1126/science.1180353, 2009.

Jo, D. S., Park, R. J., Kim, M. J., and Spracklen, D. V.: Effects of chemical aging on global secondary organic aerosol using the volatility basis set approach, Atmos. Environ., 81, 230-244, https://doi.org/10.1016/j.atmosenv.2013.08.055, 2013.

Kim, P. S., Jacob, D. J., Fisher, J. A., Travis, K., Yu, K., Zhu, L., Yantosca, R. M., Sulprizio, M. P., Jimenez, J. L., CampuzanoJost, P., Froyd, K. D., Liao, J., Hair, J. W., Fenn, M. A., Butler, C. F., Wagner, N. L., Gordon, T. D., Welti, A., Wennberg, P. O., Crounse, J. D., St. Clair, J. M., Teng, A. P., Millet, D. B., Schwarz, J. P., Markovic, M. Z., and Perring, A. E.: Sources, seasonality, and trends of southeast US aerosol: an integrated analysis of surface, aircraft, and satellite observations with the GEOS-Chem chemical transport model, Atmos. Chem. Phys., 15, 10411-10433, https://doi.org/10.5194/acp-15-104112015, 2015.

Knote, C., Hodzic, A., Jimenez, J. L., Volkamer, R., Orlando, J. J., Baidar, S., Brioude, J., Fast, J., Gentner, D. R., Goldstein, A. H., Hayes, P. L., Knighton, W. B., Oetjen, H., Setyan, A., Stark, H., Thalman, R., Tyndall, G., Washenfelder, R., Waxman, E., and Zhang, Q.: Simulation of semi-explicit mechanisms of SOA formation from glyoxal in aerosol in a 3-D model, Atmos. Chem. Phys., 14, 6213-6239, https://doi.org/10.5194/acp14-6213-2014, 2014.

Knote, C., Hodzic, A., and Jimenez, J. L.: The effect of dry and wet deposition of condensable vapors on secondary organic aerosols concentrations over the continental US, Atmos. Chem. Phys., 15, 1-18, https://doi.org/10.5194/acp-15-1-2015, 2015.

Koo, B., Knipping, E., and Yarwood, G.: 1.5-Dimensional volatility basis set approach for modeling organic aerosol in CAMx and CMAQ, Atmos. Environ., 95, 158-164, https://doi.org/10.1016/j.atmosenv.2014.06.031, 2014.

Krechmer, J. E., Pagonis, D., Ziemann, P. J., and Jimenez, J. L.: Quantification of gas-wall partitioning in Teflon environmental chambers using rapid bursts of low-volatility oxidized species generated in situ, Environ. Sci. Technol., 50, 5757-5765, 2016.

Lane, T. E., Donahue, N. M., and Pandis, S. N.: Simulating secondary organic aerosol formation using the volatility basisset approach in a chemical transport model, Atmos. Environ., 42, 7439-7451, https://doi.org/10.1016/j.atmosenv.2008.06.026, 2008 . 
Lipsky, E. M. and Robinson, A. L.: Effects of Dilution on Fine Particle Mass and Partitioning of Semivolatile Organics in Diesel Exhaust and Wood Smoke, Environ. Sci. Technol., 40, 155-162, https://doi.org/10.1021/es050319p, 2006.

Liu, J., Zhang, X., Parker, E. T., Veres, P. R., Roberts, J. M., de Gouw, J. A., Hayes, P. L., Jimenez, J. L., Murphy, J. G., Ellis, R. A., Huey, L. G., and Weber, R. J.: On the gasparticle partitioning of soluble organic aerosol in two urban atmospheres with contrasting emissions: 2. Gas and particle phase formic acid, J. Geophys. Res.-Atmos., 117, D00V21, https://doi.org/10.1029/2012jd017912, 2012a.

Liu, S., Ahlm, L., Day, D. A., Russell, L. M., Zhao, Y., Gentner, D. R., Weber, R. J., Goldstein, A. H., Jaoui, M., Offenberg, J. H., Kleindienst, T. E., Rubitschun, C., Surratt, J. D., Sheesley, R. J., and Scheller, S.: Secondary organic aerosol formation from fossil fuel sources contribute majority of summertime organic mass at Bakersfield, J. Geophys. Res.-Atmos., 117, D00V26, https://doi.org/10.1029/2012JD018170, 2012b.

Loza, C. L., Chan, A. W. H., Galloway, M. M., Keutsch, F. N., Flagan, R. C., and Seinfeld, J. H.: Characterization of Vapor Wall Loss in Laboratory Chambers, Environ. Sci. Technol., 44, 50745078, https://doi.org/10.1021/es100727v, 2010.

Ma, P. K., Zhao, Y., Robinson, A. L., Worton, D. R., Goldstein, A. H., Ortega, A. M., Jimenez, J. L., Zotter, P., Prévôt, A. S. H., Szidat, S., and Hayes, P. L.: Evaluating the impact of new observational constraints on P-S/IVOC emissions, multigeneration oxidation, and chamber wall losses on SOA modeling for Los Angeles, CA, Atmos. Chem. Phys., 17, 9237-9259, https://doi.org/10.5194/acp-17-9237-2017, 2017.

Matsui, H., Koike, M., Kondo, Y., Takami, A., Fast, J. D., Kanaya, Y., and Takigawa, M.: Volatility basis-set approach simulation of organic aerosol formation in East Asia: implications for anthropogenic-biogenic interaction and controllable amounts, Atmos. Chem. Phys., 14, 9513-9535, https://doi.org/10.5194/acp-14-9513-2014, 2014.

Matsunaga, A. and Ziemann, P. J.: Gas-wall partitioning of organic compounds in a Teflon film chamber and potential effects on reaction product and aerosol yield measurements, Aerosol Sci. Tech., 44, 881-892, 2010.

May, A. A., Levin, E. J. T., Hennigan, C. J., Riipinen, I., Lee, T., Collett, J. L., Jimenez, J. L., Kreidenweis, S. M., and Robinson, A. L.: Gas-particle partitioning of primary organic aerosol emissions: 3. Biomass burning, J. Geophys. Res.-Atmos., 118, 11327-11338, https://doi.org/10.1002/jgrd.50828, 2013a.

May, A. A., Presto, A. A., Hennigan, C. J., Nguyen, N. T., Gordon, T. D., and Robinson, A. L.: Gas-particle partitioning of primary organic aerosol emissions: (1) Gasoline vehicle exhaust, Atmos. Environ., 77, 128-139, https://doi.org/10.1016/j.atmosenv.2013.04.060, 2013 b.

May, A. A., Presto, A. A., Hennigan, C. J., Nguyen, N. T., Gordon, T. D., and Robinson, A. L.: Gas-particle partitioning of primary organic aerosol emissions: (2) diesel vehicles, Environ. Sci. Technol., 47, 8288-8296, https://doi.org/10.1021/es400782j, 2013c.

May, A. A., Nguyen, N. T., Presto, A. A., Gordon, T. D., Lipsky, E. M., Karve, M., Gutierrez, A., Robertson, W. H., Zhang, M., Brandow, C., Chang, O., Chen, S., Cicero-Fernandez, P., Dinkins, L., Fuentes, M., Huang, S.-M., Ling, R., Long, J., Maddox, C., Massetti, J., McCauley, E., Miguel, A., Na, K., Ong,
R., Pang, Y., Rieger, P., Sax, T., Truong, T., Vo, T., Chattopadhyay, S., Maldonado, H., Maricq, M. M., and Robinson, A. L.: Gas- and particle-phase primary emissions from in-use, on-road gasoline and diesel vehicles, Atmos. Environ., 88, 247-260, https://doi.org/10.1016/j.atmosenv.2014.01.046, 2014.

McVay, R. C., Zhang, X., Aumont, B., Valorso, R., Camredon, M., La, Y. S., Wennberg, P. O., and Seinfeld, J. H.: SOA formation from the photooxidation of a-pinene: systematic exploration of the simulation of chamber data, Atmos. Chem. Phys., 16, 27852802, https://doi.org/10.5194/acp-16-2785-2016, 2016.

Murphy, B. N. and Pandis, S. N.: Simulating the Formation of Semivolatile Primary and Secondary Organic Aerosol in a Regional Chemical Transport Model, Environ. Sci. Technol., 43, 4722-4728, https://doi.org/10.1021/es803168a, 2009.

Murphy, B. N., Donahue, N. M., Fountoukis, C., Dall'Osto, M., O'Dowd, C., Kiendler-Scharr, A., and Pandis, S. N.: Functionalization and fragmentation during ambient organic aerosol aging: application of the 2-D volatility basis set to field studies, Atmos. Chem. Phys., 12, 10797-10816, https://doi.org/10.5194/acp-1210797-2012, 2012.

Murphy, B. N., Donahue, N. M., Fountoukis, C., and Pandis, S. N.: Simulating the oxygen content of ambient organic aerosol with the 2D volatility basis set, Atmos. Chem. Phys., 11, 7859-7873, https://doi.org/10.5194/acp-11-7859-2011, 2011.

Murphy, D. M., Cziczo, D. J., Froyd, K. D., Hudson, P. K., Matthew, B. M., Middlebrook, A. M., Peltier, R. E., Sullivan, A., Thomson, D. S., and Weber, R. J.: Single-particle mass spectrometry of tropospheric aerosol particles, J. Geophys. Res.-Atmos., 111, D23S32, https://doi.org/10.1029/2006JD007340, 2006.

Nah, T., McVay, R. C., Zhang, X., Boyd, C. M., Seinfeld, J. H., and $\mathrm{Ng}, \mathrm{N}$. L.: Influence of seed aerosol surface area and oxidation rate on vapor wall deposition and SOA mass yields: a case study with a-pinene ozonolysis, Atmos. Chem. Phys., 16, 9361-9379, https://doi.org/10.5194/acp-16-9361-2016, 2016.

Nah, T., McVay, R. C., Pierce, J. R., Seinfeld, J. H., and Ng, N. L.: Constraining uncertainties in particle-wall deposition correction during SOA formation in chamber experiments, Atmos. Chem. Phys., 17, 2297-2310, https://doi.org/10.5194/acp17-2297-2017, 2017.

O’Brien, R. E., Laskin, A., Laskin, J., Liu, S., Weber, R., Russell, L. M., and Goldstein, A. H.: Molecular characterization of organic aerosol using nanospray desorption/electrospray ionization mass spectrometry: CalNex 2010 field study, Atmos. Environ., 68, 265-272, https://doi.org/10.1016/j.atmosenv.2012.11.056, 2013.

Ots, R., Young, D. E., Vieno, M., Xu, L., Dunmore, R. E., Allan, J. D., Coe, H., Williams, L. R., Herndon, S. C., Ng, N. L., Hamilton, J. F., Bergström, R., Di Marco, C., Nemitz, E., Mackenzie, I. A., Kuenen, J. J. P., Green, D. C., Reis, S., and Heal, M. R.: Simulating secondary organic aerosol from missing diesel-related intermediate-volatility organic compound emissions during the Clean Air for London (ClearfLo) campaign, Atmos. Chem. Phys., 16, 6453-6473, https://doi.org/10.5194/acp16-6453-2016, 2016.

Pajunoja, A., Lambe, A. T., Hakala, J., Rastak, N., Cummings, M. J., Brogan, J. F., Hao, L., Paramonov, M., Hong, J., Prisle, N. L., Malila, J., Romakkaniemi, S., Lehtinen, K. E. J., Laaksonen, A., Kulmala, M., Massoli, P., Onasch, T. B., Donahue, N. M., Riipinen, I., Davidovits, P., Worsnop, D. R., Petäjä, T., 
and Virtanen, A.: Adsorptive uptake of water by semisolid secondary organic aerosols, Geophys. Res. Lett., 42, 3063-3068, https://doi.org/10.1002/2015g1063142, 2015.

Pankow, J. F. and Asher, W. E.: SIMPOL.1: a simple group contribution method for predicting vapor pressures and enthalpies of vaporization of multifunctional organic compounds, Atmos. Chem. Phys., 8, 2773-2796, https://doi.org/10.5194/acp-8-27732008, 2008.

Presto, A. A., Hennigan, C. J., Nguyen, N. T., and Robinson, A. L.: Determination of Volatility Distributions of Primary Organic Aerosol Emissions from Internal Combustion Engines Using Thermal Desorption Gas Chromatography Mass Spectrometry, Aerosol Sci. Tech., 46, 1129-1139, https://doi.org/10.1080/02786826.2012.700430, 2012.

Pye, H. O. T. and Pouliot, G. A.: Modeling the role of alkanes, polycyclic aromatic hydrocarbons, and their oligomers in secondary organic aerosol formation, Environ. Sci. Technol., 46, 6041-6047, https://doi.org/10.1021/es300409w, 2012.

Pye, H. O. T., Pinder, R. W., Piletic, I. R., Xie, Y., Capps, S. L., Lin, Y. H., Surratt, J. D., Zhang, Z., Gold, A., Luecken, D. J., Hutzell, W. T., Jaoui, M., Offenberg, J. H., Kleindienst, T. E., Lewandowski, M., and Edney, E. O.: Epoxide pathways improve model predictions of isoprene markers and reveal key role of acidity in aerosol formation, Environ. Sci. Technol., 47, 1105611064, https://doi.org/10.1021/es402106h, 2013.

Pye, H. O. T., Murphy, B. N., Xu, L., Ng, N. L., Carlton, A. G., Guo, H., Weber, R., Vasilakos, P., Appel, K. W., Budisulistiorini, S. H., Surratt, J. D., Nenes, A., Hu, W., Jimenez, J. L., Isaacman-VanWertz, G., Misztal, P. K., and Goldstein, A. H.: On the implications of aerosol liquid water and phase separation for organic aerosol mass, Atmos. Chem. Phys., 17, 343-369, https://doi.org/10.5194/acp-17-343-2017, 2017.

Pye, H. O. T. and Seinfeld, J. H.: A global perspective on aerosol from low-volatility organic compounds, Atmos. Chem. Phys., 10, 4377-4401, https://doi.org/10.5194/acp-10-4377-2010, 2010.

Pye, H. O. T., Luecken, D. J., Xu, L., Boyd, C. M., Ng, N. L., Baker, K. R., Ayres, B. R., Bash, J. O., Baumann, K., Carter, W. P. L., Edgerton, E., Fry, J. L., Hutzell, W. T., Schwede, D. B., and Shepson, P. B.: Modeling the Current and Future Roles of Particulate Organic Nitrates in the Southeastern United States, Environ. Sci. Technol., 49, 14195-14203, https://doi.org/10.1021/acs.est.5b03738, 2015.

Rattanavaraha, W., Chu, K., Budisulistiorini, S. H., Riva, M., Lin, Y.-H., Edgerton, E. S., Baumann, K., Shaw, S. L., Guo, H., King, L., Weber, R. J., Neff, M. E., Stone, E. A., Offenberg, J. H., Zhang, Z., Gold, A., and Surratt, J. D.: Assessing the impact of anthropogenic pollution on isoprene-derived secondary organic aerosol formation in $\mathrm{PM}_{2.5}$ collected from the Birmingham, Alabama, ground site during the 2013 Southern Oxidant and Aerosol Study, Atmos. Chem. Phys., 16, 4897-4914, https://doi.org/10.5194/acp-16-4897-2016, 2016.

Riipinen, I., Rastak, N., and Pandis, S. N.: Connecting the solubility and $\mathrm{CCN}$ activation of complex organic aerosols: a theoretical study using solubility distributions, Atmos. Chem. Phys., 15, 6305-6322, https://doi.org/10.5194/acp-15-6305-2015, 2015.

Robinson, A. L., Donahue, N. M., Shrivastava, M. K., Weitkamp, E. A., Sage, A. M., Grieshop, A. P., Lane, T. E., Pierce, J. R., and Pandis, S. N.: Rethinking Organic Aerosols: Semivolatile
Emissions and Photochemical Aging, Science, 315, 1259-1262, https://doi.org/10.1126/science.1133061, 2007.

Rollins, A., Browne, E., Min, K.-E., Pusede, S., Wooldridge, P., Gentner, D., Goldstein, A., Liu, S., Day, D., and Russell, L.: Evidence for $\mathrm{NO}_{x}$ control over nighttime SOA formation, Science, 337, 1210-1212, 2012.

Ryerson, T. B., Andrews, A. E., Angevine, W. M., Bates, T. S., Brock, C. A., Cairns, B., Cohen, R. C., Cooper, O. R., de Gouw, J. A., Fehsenfeld, F. C., Ferrare, R. A., Fischer, M. L., Flagan, R. C., Goldstein, A. H., Hair, J. W., Hardesty, R. M., Hostetler, C. A., Jimenez, J. L., Langford, A. O., McCauley, E., McKeen, S. A., Molina, L. T., Nenes, A., Oltmans, S. J., Parrish, D. D., Pederson, J. R., Pierce, R. B., Prather, K., Quinn, P. K., Seinfeld, J. H., Senff, C. J., Sorooshian, A., Stutz, J., Surratt, J. D., Trainer, M., Volkamer, R., Williams, E. J., and Wofsy, S. C.: The 2010 California Research at the Nexus of Air Quality and Climate Change (CalNex) field study, J. Geophys. Res.-Atmos., 118, 5830-5866, https://doi.org/10.1002/jgrd.50331, 2013.

Saha, P. K. and Grieshop, A. P.: Exploring Divergent Volatility Properties from Yield and Thermodenuder Measurements of Secondary Organic Aerosol from alpha-Pinene Ozonolysis, Environ. Sci. Technol., 50, 5740-5749, https://doi.org/10.1021/acs.est.6b00303, 2016.

Setyan, A., Zhang, Q., Merkel, M., Knighton, W. B., Sun, Y., Song, C., Shilling, J. E., Onasch, T. B., Herndon, S. C., Worsnop, D. R., Fast, J. D., Zaveri, R. A., Berg, L. K., Wiedensohler, A., Flowers, B. A., Dubey, M. K., and Subramanian, R.: Characterization of submicron particles influenced by mixed biogenic and anthropogenic emissions using high-resolution aerosol mass spectrometry: results from CARES, Atmos. Chem. Phys., 12, 8131-8156, https://doi.org/10.5194/acp-12-8131-2012, 2012.

Setyan, A., Song, C., Merkel, M., Knighton, W. B., Onasch, T. B., Canagaratna, M. R., Worsnop, D. R., Wiedensohler, A., Shilling, J. E., and Zhang, Q.: Chemistry of new particle growth in mixed urban and biogenic emissions - insights from CARES, Atmos. Chem. Phys., 14, 6477-6494, https://doi.org/10.5194/acp14-6477-2014, 2014.

Shilling, J. E., Zaveri, R. A., Fast, J. D., Kleinman, L., Alexander, M. L., Canagaratna, M. R., Fortner, E., Hubbe, J. M., Jayne, J. T., Sedlacek, A., Setyan, A., Springston, S., Worsnop, D. R., and Zhang, Q.: Enhanced SOA formation from mixed anthropogenic and biogenic emissions during the CARES campaign, Atmos. Chem. Phys., 13, 2091-2113, https://doi.org/10.5194/acp-132091-2013, 2013.

Shiraiwa, M., Li, Y., Tsimpidi, A. P., Karydis, V. A., Berkemeier, T., Pandis, S. N., Lelieveld, J., Koop, T., and Pöschl, U.: Global distribution of particle phase state in atmospheric secondary organic aerosols, Nature Communications, 8, 15002, https://doi.org/10.1038/ncomms15002, 2017.

Shrivastava, M., Zelenyuk, A., Imre, D., Easter, R., Beranek, J., Zaveri, R. A., and Fast, J.: Implications of low volatility SOA and gas-phase fragmentation reactions on SOA loadings and their spatial and temporal evolution in the atmosphere, J. Geophys. Res.-Atmos., 118, 3328-3342, https://doi.org/10.1002/jgrd.50160, 2013.

Shrivastava, M. K., Lane, T. E., Donahue, N. M., Pandis, S. N., and Robinson, A. L.: Effects of gas particle partitioning and aging of primary emissions on urban and regional or- 
ganic aerosol concentrations, J. Geophys. Res., 113, D18301, https://doi.org/10.1029/2007jd009735, 2008.

Simon, H. and Bhave, P. V.: Simulating the degree of oxidation in atmospheric organic particles, Environ. Sci. Technol., 46, 331339, https://doi.org/10.1021/es202361w, 2012.

Simon, H., Bhave, P. V., Swall, J. L., Frank, N. H., and Malm, W. C.: Determining the spatial and seasonal variability in OM / OC ratios across the US using multiple regression, Atmos. Chem. Phys., 11, 2933-2949, https://doi.org/10.5194/acp11-2933-2011, 2011.

Skamarock, W. C., Klemp, J. B., Dudhia, J., Gill, D. O., Barker, D. M., Duda, M. G., Huang, X., Wang, W., and Powers, J. G.: A description of the Advanced Reserch WRF version 3, NCAR Technical Note NCAR/TN-475+STR, 2008.

SOAS measurement data: NOAA Earth System Research Laboratory, SENEX 2013, available at: https://esrl.noaa.gov/csd/ groups/csd7/measurements/2013senex/ (last access: 10 February 2017), 2014.

Tkacik, D. S., Presto, A. A., Donahue, N. M., and Robinson, A. L.: Secondary organic aerosol formation from intermediate-volatility organic compounds: cyclic, linear, and branched alkanes, Environ. Sci. Technol., 46, 8773-8781, https://doi.org/10.1021/es301112c, 2012.

Tsigaridis, K., Daskalakis, N., Kanakidou, M., Adams, P. J., Artaxo, P., Bahadur, R., Balkanski, Y., Bauer, S. E., Bellouin, N., Benedetti, A., Bergman, T., Berntsen, T. K., Beukes, J. P., Bian, H., Carslaw, K. S., Chin, M., Curci, G., Diehl, T., Easter, R. C., Ghan, S. J., Gong, S. L., Hodzic, A., Hoyle, C. R., Iversen, T., Jathar, S., Jimenez, J. L., Kaiser, J. W., Kirkevåg, A., Koch, D., Kokkola, H., Lee, Y. H., Lin, G., Liu, X., Luo, G., Ma, X., Mann, G. W., Mihalopoulos, N., Morcrette, J.-J., Müller, J.-F., Myhre, G., Myriokefalitakis, S., Ng, N. L., O'Donnell, D., Penner, J. E., Pozzoli, L., Pringle, K. J., Russell, L. M., Schulz, M., Sciare, J., Seland, Ø., Shindell, D. T., Sillman, S., Skeie, R. B., Spracklen, D., Stavrakou, T., Steenrod, S. D., Takemura, T., Tiitta, P., Tilmes, S., Tost, H., van Noije, T., van Zyl, P. G., von Salzen, K., Yu, F., Wang, Z., Wang, Z., Zaveri, R. A., Zhang, H., Zhang, K., Zhang, Q., and Zhang, X.: The AeroCom evaluation and intercomparison of organic aerosol in global models, Atmos. Chem. Phys., 14, 10845-10895, https://doi.org/10.5194/acp-1410845-2014, 2014.

Tsimpidi, A. P., Karydis, V. A., Zavala, M., Lei, W., Molina, L., Ulbrich, I. M., Jimenez, J. L., and Pandis, S. N.: Evaluation of the volatility basis-set approach for the simulation of organic aerosol formation in the Mexico City metropolitan area, Atmos. Chem. Phys., 10, 525-546, https://doi.org/10.5194/acp-10-5252010, 2010.

Tsimpidi, A. P., Karydis, V. A., Pozzer, A., Pandis, S. N., and Lelieveld, J.: ORACLE (v1.0): module to simulate the organic aerosol composition and evolution in the atmosphere, Geosci. Model Dev., 7, 3153-3172, https://doi.org/10.5194/gmd-7-31532014, 2014.

Tsimpidi, A. P., Karydis, V. A., Pandis, S. N., and Lelieveld, J.: Global-scale combustion sources of organic aerosols: sensitivity to formation and removal mechanisms, Atmos. Chem. Phys., 17, 7345-7364, https://doi.org/10.5194/acp-17-7345-2017, 2017.

Tuccella, P., Curci, G., Grell, G. A., Visconti, G., Crumeyrolle, S., Schwarzenboeck, A., and Mensah, A. A.: A new chemistry option in WRF-Chem v. 3.4 for the simulation of di- rect and indirect aerosol effects using VBS: evaluation against IMPACT-EUCAARI data, Geosci. Model Dev., 8, 2749-2776, https://doi.org/10.5194/gmd-8-2749-2015, 2015.

US Environmental Protection Agency: 2011 National Emissions Inventory, version 1 Technical Support Document, Report, US Environmental Protection Agency, 2014.

Wania, F., Lei, Y. D., Wang, C., Abbatt, J. P. D., and Goss, K.-U.: Using the chemical equilibrium partitioning space to explore factors influencing the phase distribution of compounds involved in secondary organic aerosol formation, Atmos. Chem. Phys., 15, 3395-3412, https://doi.org/10.5194/acp-15-3395-2015, 2015.

Washenfelder, R. A., Young, C. J., Brown, S. S., Angevine, W. M., Atlas, E. L., Blake, D. R., Bon, D. M., Cubison, M. J., de Gouw, J. A., Dusanter, S., Flynn, J., Gilman, J. B., Graus, M., Griffith, S., Grossberg, N., Hayes, P. L., Jimenez, J. L., Kuster, W. C., Lefer, B. L., Pollack, I. B., Ryerson, T. B., Stark, H., Stevens, P. S., and Trainer, M. K.: The glyoxal budget and its contribution to organic aerosol for Los Angeles, California, during CalNex 2010, J. Geophys. Res.-Atmos., 116, D00V02, https://doi.org/10.1029/2011JD016314, 2011.

Woody, M. C., Baker, K. R., Hayes, P. L., Jimenez, J. L., Koo, B., and Pye, H. O. T.: Understanding sources of organic aerosol during CalNex-2010 using the CMAQ-VBS, Atmos. Chem. Phys., 16, 4081-4100, https://doi.org/10.5194/acp16-4081-2016, 2016.

Xu, L., Guo, H., Weber, R. J., and Ng, N. L.: Chemical Characterization of Water Soluble Organic Aerosol in Contrasting Rural and Urban Environments in the Southeastern United States, Environ. Sci. Technol., 51, 78-88, https://doi.org/10.1021/acs.est.6b05002, 2017.

Xu, L., Guo, H., Boyd, C. M., Klein, M., Bougiatioti, A., Cerully, K. M., Hite, J. R., Isaacman-VanWertz, G., Kreisberg, N. M., Knote, C., Olson, K., Koss, A., Goldstein, A. H., Hering, S. V., de Gouw, J., Baumann, K., Lee, S.-H., Nenes, A., Weber, R. J., and $\mathrm{Ng}$, N. L.: Effects of anthropogenic emissions on aerosol formation from isoprene and monoterpenes in the southeastern United States, P. Natl. Acad. Sci. USA, 112, 37-42, 2015.

Yeh, G. K. and Ziemann, P. J.: Alkyl Nitrate Formation from the Reactions of C8-C14 n-Alkanes with OH Radicals in the Presence of $\mathrm{NO}_{x}$ : Measured Yields with Essential Corrections for GasWall Partitioning, J. Phys. Chem. A, 118, 8147-8157, 2014.

Yu, S., Eder, B., Dennis, R., Chu, S.-H., and Schwartz, S. E.: New unbiased symmetric metrics for evaluation of air quality models, Atmos. Sci. Lett., 7, 26-34, https://doi.org/10.1002/asl.125, 2006.

Zaveri, R. A., Shaw, W. J., Cziczo, D. J., Schmid, B., Ferrare, R. A., Alexander, M. L., Alexandrov, M., Alvarez, R. J., Arnott, W. P., Atkinson, D. B., Baidar, S., Banta, R. M., Barnard, J. C., Beranek, J., Berg, L. K., Brechtel, F., Brewer, W. A., Cahill, J. F., Cairns, B., Cappa, C. D., Chand, D., China, S., Comstock, J. M., Dubey, M. K., Easter, R. C., Erickson, M. H., Fast, J. D., Floerchinger, C., Flowers, B. A., Fortner, E., Gaffney, J. S., Gilles, M. K., Gorkowski, K., Gustafson, W. I., Gyawali, M., Hair, J., Hardesty, R. M., Harworth, J. W., Herndon, S., Hiranuma, N., Hostetler, C., Hubbe, J. M., Jayne, J. T., Jeong, H., Jobson, B. T., Kassianov, E. I., Kleinman, L. I., Kluzek, C., Knighton, B., Kolesar, K. R., Kuang, C., Kubátová, A., Langford, A. O., Laskin, A., Laulainen, N., Marchbanks, R. D., Mazzoleni, C., Mei, F., Moffet, R. C., Nelson, D., Obland, M. D., Oetjen, H., Onasch, 
T. B., Ortega, I., Ottaviani, M., Pekour, M., Prather, K. A., Radney, J. G., Rogers, R. R., Sandberg, S. P., Sedlacek, A., Senff, C. J., Senum, G., Setyan, A., Shilling, J. E., Shrivastava, M., Song, C., Springston, S. R., Subramanian, R., Suski, K., Tomlinson, J., Volkamer, R., Wallace, H. W., Wang, J., Weickmann, A. M., Worsnop, D. R., Yu, X.-Y., Zelenyuk, A., and Zhang, Q.: Overview of the 2010 Carbonaceous Aerosols and Radiative Effects Study (CARES), Atmos. Chem. Phys., 12, 7647-7687, https://doi.org/10.5194/acp-12-7647-2012, 2012.

Zhang, Q., Jimenez, J. L., Canagaratna, M. R., Allan, J. D., Coe, H., Ulbrich, I., Alfarra, M. R., Takami, A., Middlebrook, A. M., Sun, Y. L., Dzepina, K., Dunlea, E., Docherty, K., DeCarlo, P. F., Salcedo, D., Onasch, T., Jayne, J. T., Miyoshi, T., Shimono, A., Hatakeyama, S., Takegawa, N., Kondo, Y., Schneider, J., Drewnick, F., Borrmann, S., Weimer, S., Demerjian, K., Williams, P., Bower, K., Bahreini, R., Cottrell, L., Griffin, R. J., Rautiainen, J., Sun, J. Y., Zhang, Y. M., and Worsnop, D. R.: Ubiquity and dominance of oxygenated species in organic aerosols in anthropogenically-influenced Northern Hemisphere midlatitudes, Geophys. Res. Lett., 34, L13801, https://doi.org/10.1029/2007GL029979, 2007.

Zhang, Q. J., Beekmann, M., Drewnick, F., Freutel, F., Schneider, J., Crippa, M., Prevot, A. S. H., Baltensperger, U., Poulain, L., Wiedensohler, A., Sciare, J., Gros, V., Borbon, A., Colomb, A., Michoud, V., Doussin, J.-F., Denier van der Gon, H. A. C., Haeffelin, M., Dupont, J.-C., Siour, G., Petetin, H., Bessagnet, B., Pandis, S. N., Hodzic, A., Sanchez, O., Honoré, C., and Perrussel, O.: Formation of organic aerosol in the Paris region during the MEGAPOLI summer campaign: evaluation of the volatility-basis-set approach within the CHIMERE model, Atmos. Chem. Phys., 13, 5767-5790, https://doi.org/10.5194/acp13-5767-2013, 2013.

Zhang, X., Liu, J., Parker, E. T., Hayes, P. L., Jimenez, J. L., de Gouw, J. A., Flynn, J. H., Grossberg, N., Lefer, B. L., and Weber, R. J.: On the gas-particle partitioning of soluble organic aerosol in two urban atmospheres with contrasting emissions: 1. Bulk water-soluble organic carbon, J. Geophys. Res.-Atmos., 117, D00V16, https://doi.org/10.1029/2012jd017908, 2012.
Zhang, X., Cappa, C. D., Jathar, S. H., McVay, R. C., Ensberg, J. J., Kleeman, M. J., and Seinfeld, J. H.: Influence of vapor wall loss in laboratory chambers on yields of secondary organic aerosol, $\mathrm{P}$. Natl. Acad. Sci., 111, 5802-5807, 2014.

Zhang, X., Schwantes, R. H., McVay, R. C., Lignell, H., Coggon, M. M., Flagan, R. C., and Seinfeld, J. H.: Vapor wall deposition in Teflon chambers, Atmos. Chem. Phys., 15, 4197-4214, https://doi.org/10.5194/acp-15-4197-2015, 2015.

Zhao, B., Wang, S., Donahue, N. M., Jathar, S. H., Huang, X., Wu, W., Hao, J., and Robinson, A. L.: Quantifying the effect of organic aerosol aging and intermediate-volatility emissions on regional-scale aerosol pollution in China, Scientific Reports, 6, 28815, https://doi.org/10.1038/srep28815, 2016a.

Zhao, Y., Nguyen, N. T., Presto, A. A., Hennigan, C. J., May, A. A., and Robinson, A. L.: Intermediate Volatility Organic Compound Emissions from On-Road Gasoline Vehicles and Small OffRoad Gasoline Engines, Environ. Sci. Technol., 50, 4554-4563, https://doi.org/10.1021/acs.est.5b06247, 2016b.

Zhao, Y., Kreisberg, N. M., Worton, D. R., Isaacman, G., Gentner, D. R., Chan, A. W. H., Weber, R. J., Liu, S., Day, D. A., Russell, L. M., Hering, S. V., and Goldstein, A. H.: Sources of organic aerosol investigated using organic compounds as tracers measured during CalNex in Bakersfield, J. Geophys. Res.-Atmos., 118, 11388-11398, https://doi.org/10.1002/jgrd.50825, 2013.

Zhao, Y., Hennigan, C. J., May, A. A., Tkacik, D. S., de Gouw, J. A., Gilman, J. B., Kuster, W. C., Borbon, A., and Robinson, A. L.: Intermediate-volatility organic compounds: a large source of secondary organic aerosol, Environ. Sci. Technol., 48, 13743 13750, https://doi.org/10.1021/es5035188, 2014. 